\title{
Modern sediment records of hydroclimatic extremes and associated potential contaminant mobilization in semi-arid environments: lessons learnt from recent flood-drought cycles in southern Botswana
}

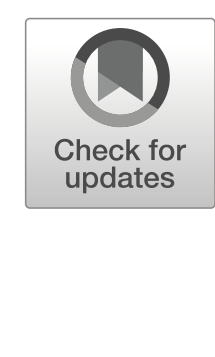

\author{
Fulvio Franchi ${ }^{1}$ - Jason M. E. Ahad ${ }^{2}$. Josie Geris ${ }^{3} \cdot$ Gaone Jhowa $^{1} \cdot$ Alfred K. Petros $^{4}$ • Jean-Christophe Comte ${ }^{3}$
}

Received: 2 June 2019 / Accepted: 3 September 2019 / Published online: 18 November 2019

(C) The Author(s) 2019

\begin{abstract}
Purpose The aim of this work was to identify and analyze the records of flood-drought cycles as preserved in the sediments of the Notwane reservoir, southern Botswana, in order to better understand how extreme events affect water and sediment quality. This work represents the first attempt to study the reservoir sediments in arid to semi-arid environments and suggests that they could be used as proxies for the characterization of the effects of flood-drought cycles.

Materials and methods For the first time in an arid context like Botswana, sediments from artificial reservoirs were explored through correlating sediment records with the presence and quantity of pollutants in the reservoir's wider arid and semi-arid catchment after the latest extreme flood event of 2017. Sediments from the Notwane reservoir were collected with a push corer to a maximum depth of $80 \mathrm{~cm}$. Sediments were then analyzed for grain size distribution, organic matter content, and concentrations of heavy metals (Fe, $\mathrm{Zn}$, $\mathrm{Cu}, \mathrm{Cr}$, and $\mathrm{Pb}$ ). Concentrations of heavy metals from surface water and groundwater were compared with the metal profiles from the sediment cores and with rainfall series from the CHIRPS (Climate Hazards Group InfraRed Precipitation with Stations) database. Results and discussion The sediments from Notwane reservoir clearly showed two flood couplets characterized by fining upward beds. Water quality data from Notwane reservoir and the surrounding aquifer showed peaks of contaminants following rainfall. Although the couplets found in the sediment record were not always clearly coupled with peaks of metals, some correlation was found between the vertical distribution of metals within the sediments and the most recent sequence and the seasonal metal variation in water. Overall, trace metal contents were very low: $<1 \mathrm{mg} \mathrm{L}^{-1}$ for $\mathrm{Cu}$ and $\mathrm{Zn}$ and $<2 \mathrm{mg} \mathrm{L}^{-1}$ for $\mathrm{Cr}$ and $\mathrm{Pb}$, well below the sediment quality assessment guidelines (SQGs), indicating that the above-average precipitations of the last 10 years did not noticeably contribute to the input of heavy metal contaminants in the reservoir sediments.

Conclusions The 2016/17 Dineo cyclone flood was triggered by above-average rainfall, preceded by a 4-year period of severe drought. The deterioration of the basin during the drought has enhanced the effects of the flood, worsening the damages on structures and livelihoods. The lessons learnt from the Dineo cyclone in Botswana highlight the importance of integrated studies that combine hydrological data, rainfall series, and sediments. It is recommended to extend the research for longer time periods.
\end{abstract}

Keywords Botswana $\cdot$ Dineo cyclone $\cdot$ Flood $\cdot$ Limpopo catchment $\cdot$ Sediments contamination

Responsible editor: Marcel van der Perk

Electronic supplementary material The online version of this article (https://doi.org/10.1007/s11368-019-02454-9) contains supplementary material, which is available to authorized users.

Fulvio Franchi

franchif@biust.ac.bw

1 Earth and Environmental Science Department, Botswana International University of Science and Technology, Private Bag 16, Palapye, Botswana
2 Geological Survey of Canada, Natural Resources Canada, 490 rue de la Couronne, Québec, QC G1K 9A9, Canada

3 School of Geosciences, University of Aberdeen, King's College, Aberdeen, UK

4 Department of Water and Sanitation, Ministry of Land Management Water and Sanitation Services, Private Bag, 0029 Gaborone, Botswana 


\section{Introduction}

Semi-arid regions receive low annual rainfall, mainly concentrated in a short rainy season followed by a prolonged dry season. These regions are characterized by extreme climate variability and are subject to droughts and heavy, discontinuous rainfall periods often followed by floods (Bisantino et al. 2011; Al-Taani et al. 2015). In arid to semi-arid environments, even the long-awaited rain after a prolonged dry season can become a threat, especially if it comes as an "exceptionally" intense rainfall event (Tsheko 2003; Ghazavi et al. 2012; AlTaani et al. 2015; Alemaw et al. 2016). In fact, in this environment, the high intensity and short duration of rainfall causes extensive runoff and floods (e.g., Ghazavi et al. 2012). In arid to semi-arid areas, the role of the erosive energy of flood events is enhanced by climatic seasonality, physiography of the basin, lithology, and the extent of soil erosion due to human activities (Soler et al. 2007; Bisantino et al. 2011). Prolonged drought causing a drastic reduction in vegetation cover can have a direct effect on the erosion of the soils (e.g., Dunbar et al. 2010; Goode et al. 2012; Vaezi et al. 2017). As a result, sediment yields might be larger compared to more humid environments (Goode et al. 2012). In semi-arid environments, the amount of precipitation is sufficient to produce soils but not in sustaining the vegetation required to stabilize the hillslopes throughout the year, resulting in enhanced erosion during heavy rains (Bisantino et al. 2011; Goode et al. 2012; Al-Taani et al. 2015) with high suspended sediment concentrations in rivers during floods (Megnounif et al. 2007; Bisantino et al. 2011). Hence, storm intensity and duration are important controls on the sediment production in semi-arid basins, and therefore, climate-driven variations are likely to produce changes in sediment yields (e.g., Goode et al. 2012). It is therefore paramount to understand the effects of weather and climate within the sediment record and, for this reason, the study of flood couplets within the sediments of artificial reservoirs may be crucial (e.g., Zhao et al. 2017). While existing monitoring systems can shed light on recent and ongoing events, sediments can be used to assess past extreme climate events, filling important knowledge gaps due to a lack of monitoring and reporting.

Sediments from check dams can also provide information on the erosion and denudation rate in the catchment (e.g., Romero-Díaz et al. 2007; Vaezi et al. 2017; Zhao et al. 2017) and insight into anthropogenic effects on the physiography of the basin (e.g., Foster et al. 2012; Zhu et al. 2017). This includes the enhancement of land degradation due to human activities that can have dual impacts on the quantity and quality of the surface water in reservoirs by increasing silting, surface runoff, and pollutant transport (Saft et al. 2015, 2016; Zhu et al. 2017).

The sediments from check dams in arid and semi-arid environments can contribute to transportation, mobilization, and redistribution of contaminants such as heavy metals in the catchment (Goher et al. 2014; El Azhari et al. 2016; Zhu et al. 2017). Organic matter (OM) and heavy metals derived from intensive agriculture and livestock industry can accumulate in the reservoir via soil erosion caused by exceptional rains and floods (He et al. 2005; Zhu et al. 2017). Heavy metals can also originate from vehicle exhausts and road runoff within the catchment (Legret and Pagotto 1999; Mangani et al. 2005; Zhu et al. 2017). Heavy metals absorbed to particulates and clay minerals can be released into groundwater and surface water in response to a variety of environmental changes (Prusty et al. 1994; Wen and Allen 1999; El Azhari et al. 2016). During flood events, heavy metals can be released from particulates into the water (Peraza-Castro et al. 2016), increasing their bioavailability and disturbing water treatment plant operations (Bryant et al. 2011; Zhu et al. 2017). Heavy metals in the aquatic ecosystem, either resulting from natural or anthropogenic inputs, can pose serious threats to the environment and also to human beings by entering the food chain via bioaccumulating aquatic organisms (e.g., MacDonald et al. 2000; Gómez-Álvarez et al. 2011; Zhu et al. 2017). Compared to temperate environments, the magnitude of heavy metal remobilization in semi-arid and arid environments is less understood (Hudson-Edwards et al. 1998; Taylor and Kesterton 2002).

The main aim of this work is to examine the environmental impacts of the 2016/2017 and other recent flood events in Botswana by coupling high spatiotemporal resolution hydrological monitoring, rainfall series, and characterization of flood sediments within reservoirs. Here, the focus is on the characterization of the first $80 \mathrm{~cm}$ ca. of dam sediments from the Notwane check dam in the Gaborone dam catchment (Fig. 1), including grain size analyses, $\mathrm{OM}$ contents, ${ }^{14} \mathrm{C}$ radiometric dating, and distribution of heavy metals ( $\mathrm{Fe}, \mathrm{Zn}, \mathrm{Cu}$, $\mathrm{Cr}$, and $\mathrm{Pb}$ ). The objectives of this work are to (i) identify the sediments couplets indicative of flood-drought cycles in the Notwane reservoir shallow sediments, (ii) describe the vertical distribution of $\mathrm{OM}$ and heavy metals and their relationships with the identified flood-drought cycles, and (iii) assess whether heavy metal concentrations in dam sediments could act as proxies to better understand the dynamics of these contaminants in water resources after floods at the reservoir catchment scale. The potential hazard posed by heavy metals dispersed in the environment can be assessed using different pollution indices and multivariate statistical techniques (Varol 2011; Tang et al. 2015; Zhu et al. 2017). Here, we use the geoaccumulation index ( $\mathrm{I}_{\text {geo }}$, Müller 1969) to assess the geological background in the basin by comparing concentrations from the samples with thresholds calculated from the geology of the area (e.g., Zhu et al. 2017). Moreover, the concentrations from the studied sediments are compared with consensus-based sediment quality guidelines for freshwater ecosystems (SQGs; MacDonald et al. 2000) for the 


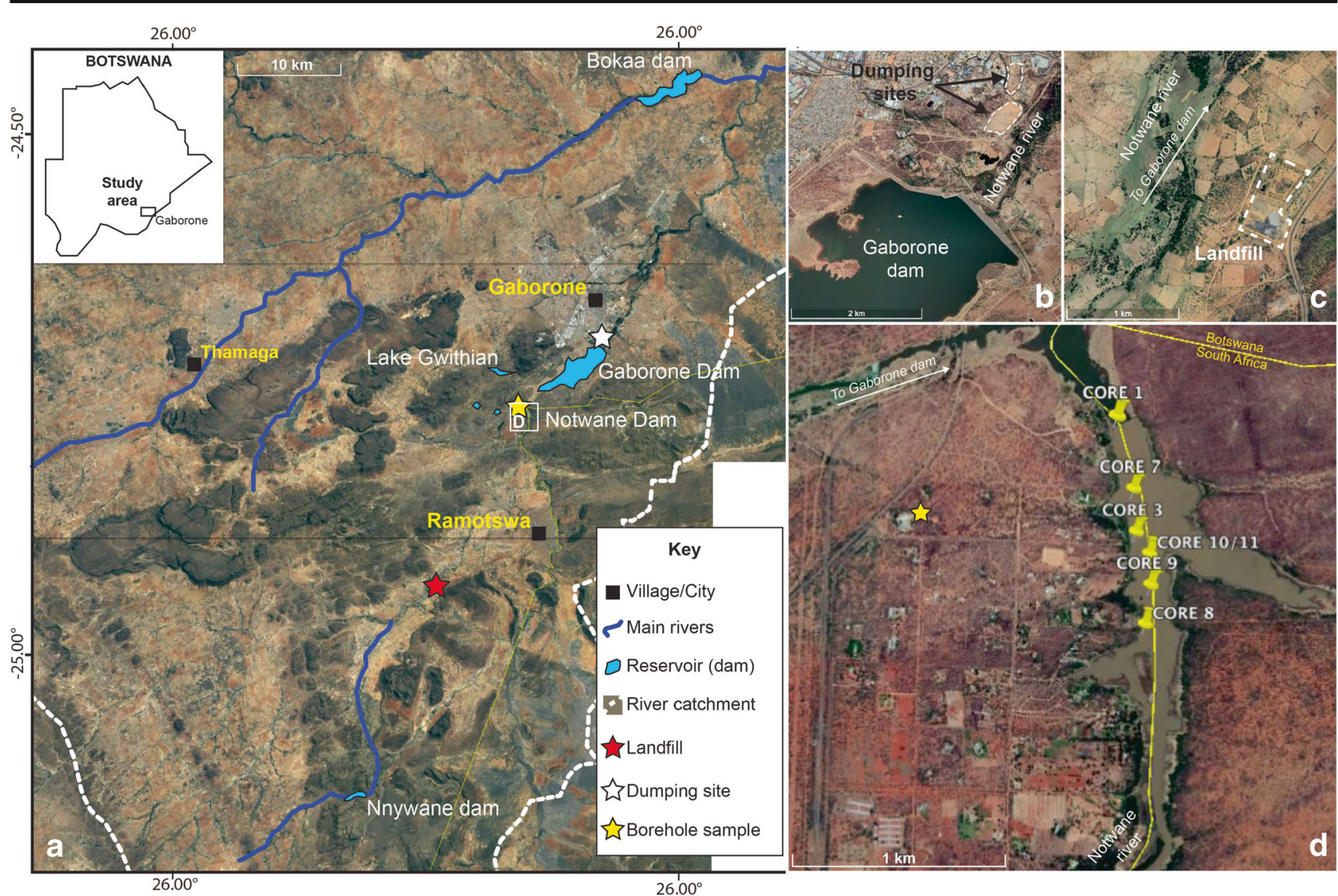

Fig. 1 a Satellite imagine of the upper and lower Notwane River catchment in Botswana showing locations of PULA project monitoring sites. White square outlines the area shown in $\mathbf{d}$. b Close up of the Gaborone Dam embankment wall and dumping sites along the
Notwane River. c Close up of the landfill near the village of Otse. d Close up of the Notwane Dam (see a for location) showing location of the sampling sites. All imagines are from Google Earth 2019

reaching full capacity for the first time in 10 years, it also resulted in significant damage to infrastructure and possible mobilization of contaminants from landfills and urban areas. Floods can pose a serious threat as they potentially induce water resource pollution from (unsealed) dumping sites and landfills (Fig. 1) via mobilization and deposition of fine sediments that alter dam efficiency and water quality, highlighting the dual effects of floods in this type of environment.

The Notwane Dam reservoir (Fig. 1) is ca. $0.5 \mathrm{~km}^{2}$ impoundment basin build in the upper catchment of the Notwane River located in southeastern Botswana (between $23^{\circ} \mathrm{S}$ and $25^{\circ} \mathrm{S}$ and $25^{\circ} \mathrm{E}$ and $27^{\circ} \mathrm{E}$ ). The Notwane is a check dam that has been engineered as a sediment trap for Gaborone reservoir, which provides a major water supply for the capital city of Botswana, Gaborone (Alemaw et al. 2016). The area is one of the more densely populated of the country and is dotted by illegal dumping sites and landfills (Fig. 1b, c).

The Notwane River is an ephemeral river that forms part of the Limpopo River catchment in Botswana, with a subcatchment covering a total natural drainage area of $18,263 \mathrm{~km}^{2}$ (Alemaw et al. 2016). The upper Notwane River catchment (3935 $\mathrm{km}^{2}$ at the site of Notwane reservoir) 
drains an area characterized by the Neoarchean volcanosedimentary sequence (Fig. 2) of the Lobatse Group, the Gaborone Granites, and the Paleoproterozoic sediments of the Transvaal Supergroup (for a review see: Franchi 2018; Franchi and Mapeo 2019). In the study area, the Lobatse Group is comprised of the alkali porphyritic rhyolites of the Kanye and Nnywane Formations overlaid by the argillites, epiclastic sandstones, and conglomerates of the Mogobane Formation (Modie 1999; Franchi and Mapeo 2019). The Transvaal Supergroup sequence in the area is characterized by the karstified dolomite of the Taupone Dolomite Group (known in the Lobatse-Ramotswa area as Ramotswa Dolomite Formation) and coarse siliciclastic deposits of the Bevet's Conglomerate Member and by the sediments of the Ditojana and Tlaameng Formations (Key 1983; Mapeo and Wingate 2006).

The catchment of the Notwane river in the upstream area of the reservoir can be subdivided into three zones based on the regional geology (Fig. 2): (i) the upper part from the source to the Nnywane Dam (Fig. 1a) and in the northern area around Thamaga village, where the dominant lithology is porphyritic alkali feldspar granites of the Thamaga Formation (Gaborone Granite) and the porphyritic rhyolites of the Kanye Formation; (ii) from the Nnywane Dam to the outskirt of Gaborone the geology is dominated by the sediments of the Lobatse Group and the Transvaal Supergroup; (iii) the area around Gaborone, again characterized by porphyritic alkali feldspar granites and by the porphyritic rhyolites of the Kanye Formation (for a review see Franchi and Mapeo 2019). Granites and rhyolites form low productivity, weathered/fractured aquifers while the Ramotswa dolomite (Taupone Dolomite Group) forms a productive, regionally important karstic aquifer (McGill et al. 2019). The Notwane Dam (and the Gaborone Dam) rests on top of the porphyritic alkali feldspar granites of the Gaborone Granite and the Kanye Formation rhyolites (Fig. 2). The bedrock in the area upstream from the reservoir is overlain by clay loam Leptosols (31\%), sandy clay loam Acrisols (22\%), and a mixture of various sandy loam soils. Local land use consists of urban areas and some closed to open (>15\%) herbaceous vegetation.

\section{Materials and methods}

\subsection{Sampling techniques}

Seven sediment cores from the Notwane reservoir (Fig. 1d) were collected using a push corer equipped with extension rods from shore or from a small boat (Table 1). The cores were collected using $50 \mathrm{~mm}$ diameter PVC pipes and stored at $4{ }^{\circ} \mathrm{C}$ for water retention. The cores where then split in half, photographed, and sub-sampled for grain size and geochemical analysis. Color variation, sedimentary structures, and deformation structures along the core profiles have been described (Figs. 3 and 4). Subsamples were obtained with a metal spatula every $2 \mathrm{~cm}$. Samples of sediment from the cores were analyzed for their particle size distribution, organic matter content, and concentrations of heavy metals $(\mathrm{Cr}, \mathrm{Fe}, \mathrm{Ni}, \mathrm{Cu}, \mathrm{Zn}, \mathrm{Pb})$. These specific metals were selected because (i) they typically serve as proxies for the assessment of risk related to pollutants (c.f. Al-Taani et al. 2015; Zhu et al. 2017), and (ii) geological background values were available (from the Transvaal Supergroup and Kanye Formation).

\subsection{Grain size and organic matter content}

A few grams of sediment were dispersed into distilled water, and grain size distribution was analyzed with a Malvern Mastersizer 3000 laser diffraction particle size analyzer available at Botswana International University of Science and Technology (BIUST). The median $\left(\mathrm{D}_{50}\right)$ of grain size distribution for each of the subsamples is reported in Online Resources 1 of the Electronic Supplementary Material.

The OM content of the sediments was obtained by measuring the loss on ignition (LOI) of bulk sediments after calcination in a muffle furnace. The porcelain crucibles were preheated in a muffle furnace for $1 \mathrm{~h}$ at $375^{\circ} \mathrm{C}$ and after cooling transferred into a desiccator for further cooling and weighed. Samples were dried at $105^{\circ} \mathrm{C}$ for $24 \mathrm{~h}$ and weighed. The dried samples were then heated for $16 \mathrm{~h}$ at $550{ }^{\circ} \mathrm{C}$. Organic matter contents are reported in Online Resources 1 (Electronic Supplementary Material).

\subsection{Heavy metal concentrations in sediments}

Approximately 100 samples of sediments from selected intervals of the cores (Online Resources 1 of the Electronic Supplementary Material) were analyzed for trace metal distribution (Fe, $\mathrm{Zn}, \mathrm{Cu}, \mathrm{Cr}$, and $\mathrm{Pb}$ ) using an Agilent 4200 Microwave Plasma-Atomic Emission Spectrometer (MPAES) at BIUST. About $1 \mathrm{~g}$ of sample was treated with 10 $15 \mathrm{ml}$ of $65 \%$ nitric acid at $60{ }^{\circ} \mathrm{C}$ for a period of $4 \mathrm{~h}$. The samples were then filtered at $<0.45 \mu \mathrm{m}$ and brought to $50 \mathrm{ml}$ adding Milli-Q distilled water. Average standard deviations were as follows: $\mathrm{Fe} \% \mathrm{RSD}=1.81 ; \mathrm{Zn} \% \mathrm{RSD}=4.02 ; \mathrm{Cu}$ $\% \mathrm{RSD}=1.43 ; \mathrm{Ni} \% \mathrm{RSD}=21.22 ; \mathrm{Cr} \% \mathrm{RSD}=0.82 ; \mathrm{Pb}$ $\% \mathrm{RSD}=1.72$. The results from $\mathrm{Ni}$ have been excluded from the work because of the majority of measurements were below the detection limit. Detection limits for the metals reported here (as weight of dry sediment) were as follows: $\mathrm{Cr}=$ $0.8 \mu \mathrm{g} \mathrm{kg}^{-1}, \mathrm{Fe}=1.7 \mu \mathrm{g} \mathrm{kg}^{-1} ; \mathrm{Cu}=0.5 \mu \mathrm{g} \mathrm{kg}^{-1} ; \mathrm{Zn}=$ $28 \mu \mathrm{g} \mathrm{kg}^{-1} ; \mathrm{Pb}=2.5 \mu \mathrm{g} \mathrm{kg}^{-1}$. 


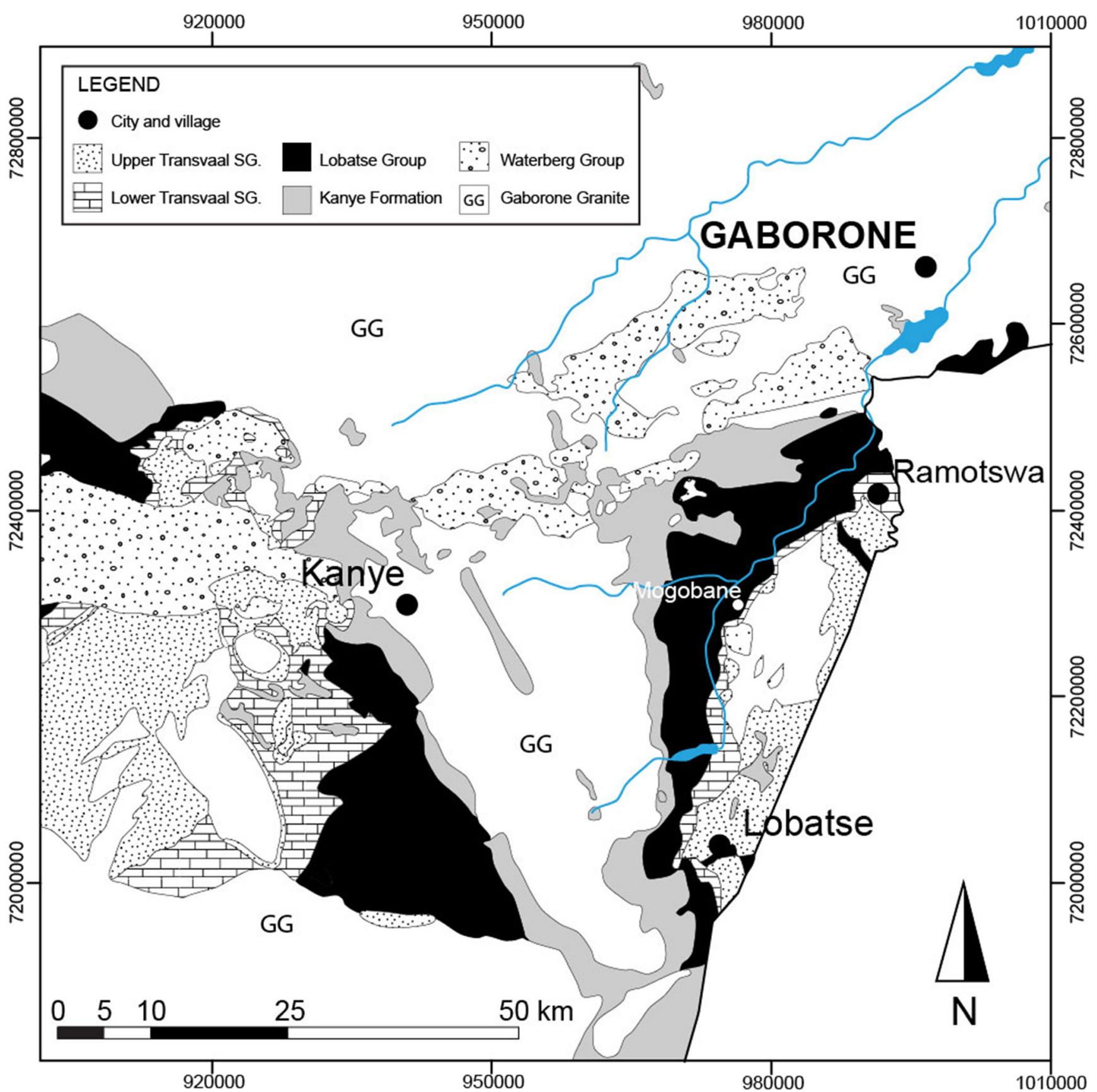

Fig. 2 Schematic geological map of south-east Botswana including the Notwane River sub-catchment (modified from Franchi and Mapeo 2019)

\subsection{Heavy metal pollution indices}

The geoaccumulation index ( $\left.\mathrm{I}_{\mathrm{geo}}\right)$ was calculated to discriminate between the geological background concentration and relative levels of anthropogenic heavy metal inputs in the sediments (Online Resources 2 of the Electronic Supplementary Material). The $\mathrm{I}_{\text {geo }}$ was determined using the following equation from Müller (1969):

$\mathrm{I}_{\mathrm{geo}}=\log _{2}\left[\mathrm{M}_{\mathrm{s}} / 1.5 \mathrm{M}_{\mathrm{b}}\right]$ where $\mathrm{M}_{\mathrm{s}}$ is the metal content in the sample $\left(\mathrm{mg} \mathrm{L}^{-1}\right)$ and $\mathrm{M}_{\mathrm{b}}$ is the metal content in the background material $\left(\mathrm{mg} \mathrm{L}^{-1}\right)$. As outlined in the previous section, the bedrock in the upper Notwane River catchment is mostly igneous with minor dolomitic terrain and siliciclastic deposits. The background is therefore calculated as an average of the composition of the Ramonnedi Formation dolomites and Gaborone Granites as published in Franchi (2018) and Lowe (1995), respectively (Table 2). The values obtained are then compared with $\mathrm{I}_{\text {geo }}$ classes by Müller (1981): class $0=$ unpolluted $\left(\mathrm{I}_{\mathrm{geo}}<0\right)$, class 
Table 1 Length and location of the sediment cores from the Notwane Dam

\begin{tabular}{llllll}
\hline Core ID & Dam & Length $(\mathrm{cm})$ & Coordinates & \multirow{2}{*}{ Date of collection } \\
\cline { 4 - 5 } & & & Lat. & Long. & \\
\hline 1 & Notwane & 35 & $\mathrm{~S} 24.758735$ & E025.849691 & 22 Nov. 2017 \\
3 & Notwane & 60 & $\mathrm{~S} 24.763370$ & E025.850608 & 22 Nov. 2017 \\
7 & Notwane & 85 & $\mathrm{~S} 24.76161$ & E025.85048 & 22 Nov. 2017 \\
8 & Notwane & 70 & $\mathrm{~S} 24.76714$ & E025.85104 & 19 Feb. 2018 \\
9 & Notwane & 35 & $\mathrm{~S} 24.765531$ & E025.851270 & 19 Feb. 2018 \\
10 & Notwane & 50 & $\mathrm{~S} 24.76426$ & E025.85121 & 19 Feb. 2018 \\
11 & Notwane & 35 & $\mathrm{~S} 24.76426$ & E025.85121 & 19 Feb. 2018 \\
\hline
\end{tabular}

$1=$ from unpolluted to moderately polluted $\left(0<\mathrm{I}_{\text {geo }}<1\right)$, class $2=$ moderately polluted $\left(1<\mathrm{I}_{\mathrm{geo}}<2\right)$; class $3=$ from moderately to strongly polluted $\left(2<\mathrm{I}_{\text {geo }}<3\right)$, class $4=$ strongly polluted $\left(3<\mathrm{I}_{\text {geo }}<4\right)$; class $5=$ from strongly to extremely polluted $\left(4<\mathrm{I}_{\text {geo }}<5\right)$, class $6=$ extremely polluted $\left(\mathrm{I}_{\mathrm{geo}}>5\right)$.

The trace metal distributions within the Notwane Dam sediments were then compared with the sediment quality assessment guidelines (SQGs) in order to assess the risk due to heavy metal pollution (MacDonald et al. 2000; Farkas et al. 2007). In this analysis, the potential of contamination is expressed as threshold effect concentration (TEC) and probable effect concentration (PEC) for each of the heavy metals considered (e.g., MacDonald et al. 2000; Zhu et al. 2017).

\subsection{Radiocarbon analyses}

Six layers rich in plant remains from six different cores (Table 3) were submitted to the André E. Lalonde Accelerator Mass Spectrometry (AMS) Laboratory at the University of Ottawa (Ottawa, ON, Canada) for ${ }^{14} \mathrm{C}$ analysis using their $3 \mathrm{MV}$ tandem accelerator mass spectrometer (High Voltage Engineering). Sample pretreatment techniques and definitions of media codes as well as specifications on the hardware set-up can be found in Crann et al. (2017) and StJean et al. (2017). The samples were pretreated using an acidalkali-acid (AAA) wash, which uses $\mathrm{HCl}$ to remove carbonates, $\mathrm{NaOH}$ to remove humic acid, and $\mathrm{HCl}$ again to neutralize the sample and remove any $\mathrm{CO}_{2}$ introduced during the alkali wash. Radiocarbon data (Table 3) is reported following the conventions recommended by Millard (2014). For the one sample where the fraction modern carbon $\left(\mathrm{F}^{14} \mathrm{C}\right)$ was less than 1, the ShCal13 (southern hemisphere calibration curve 2013) was used to calibrate radiocarbon ages (Reimer et al. 2013). For the remaining five samples with $\mathrm{F}^{14} \mathrm{C}$ greater than 1 , the post-bomb atmospheric curve was used (Hua et al. 2013). $\mathrm{F}^{14} \mathrm{C}$ values were also compared with the trends reported by Turnbull et al. (2017) that cover records of ${ }^{14} \mathrm{C}$ in the southern hemisphere up to the year 2015.

\subsection{Water quality and rainfall data}

Samples of surface and groundwater were collected from the Notwane reservoir and a nearby borehole (400 $\mathrm{m}$ from the reservoir) in the period April 2017-May 2018 (Fig. 1). Water samples were analyzed for a full array for $\mathrm{Cr}, \mathrm{Ni}, \mathrm{Cu}, \mathrm{Zn}$, and $\mathrm{Pb}$, obtained with an Agilent 7900 ICP-MS (induced coupled plasma-mass spectrometer) whereas Fe analyses were performed with a MP-AES instrument. All analyses were done at the Chemistry department laboratory at the University of Aberdeen. Analyses were conducted on $30 \mathrm{ml}$ (for $\mathrm{Cr}, \mathrm{Ni}, \mathrm{Cu}$, $\mathrm{Zn}$ and $\mathrm{Pb}$ ) or $10 \mathrm{ml}$ (for $\mathrm{Fe}$ ) of water. The limits of detection for each element are as follows: $\mathrm{Cr}=0.009 \mu \mathrm{g} \mathrm{\textrm {L } ^ { - 1 }}, \mathrm{Fe}=$ $0.05 \mu \mathrm{g} \mathrm{L}^{-1}, \mathrm{Ni}=0.078 \mu \mathrm{g} \mathrm{L}^{-1}, \mathrm{Cu}=0.059 \mu \mathrm{g} \mathrm{L}^{-1}, \mathrm{Zn}=$ $0.078 \mu \mathrm{g} \mathrm{L}^{-1}, \mathrm{~Pb}=0.004 \mu \mathrm{g} \mathrm{\textrm {L } ^ { - 1 }}$. For groundwater, $\mathrm{Cu}$ and $\mathrm{Zn}$ are not reported here as concentrations were consistently below the detection limit.

The rainfall series include satellite data from 1981 to 2017 from the CHIRPS database (Climate Hazards Group, https://doi. org/10.15780/G2RP4Q). The rainfall series from 1996 to 2018 CHIRPS data for the Notwane River catchment are plotted in Fig. 5.

\section{Results}

\subsection{Core description}

The detailed description of the cores is reported in Table 4. Core 1 was collected close to the embankment wall of the dam (Fig. 1d). This core shows three horizons characterized by an horizon at ca. $10 \mathrm{~cm}$ depth with large plant debris which is not seen in the other cores (Fig. 3a). The metal concentrations in Core 1 show a gradual decrease from around $30 \mathrm{~cm}$ to $\mathrm{ca} .17 \mathrm{~cm}$ depth where all metal concentrations reach a minimum (although $\mathrm{Pb}$ is lower at the very bottom of the core, Fig. 3a). The metal concentrations then sharply increase in the top $17 \mathrm{~cm}$ to values similar to the bottom of the core (Fig. 3a): $\mathrm{Cr}$ increases from 0.04 to 


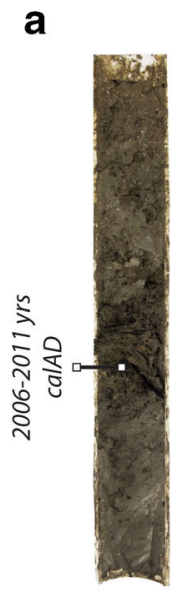

Grain size (D50) $(\mu \mathrm{m})$

Fe (ppm)

Other metals (ppm)
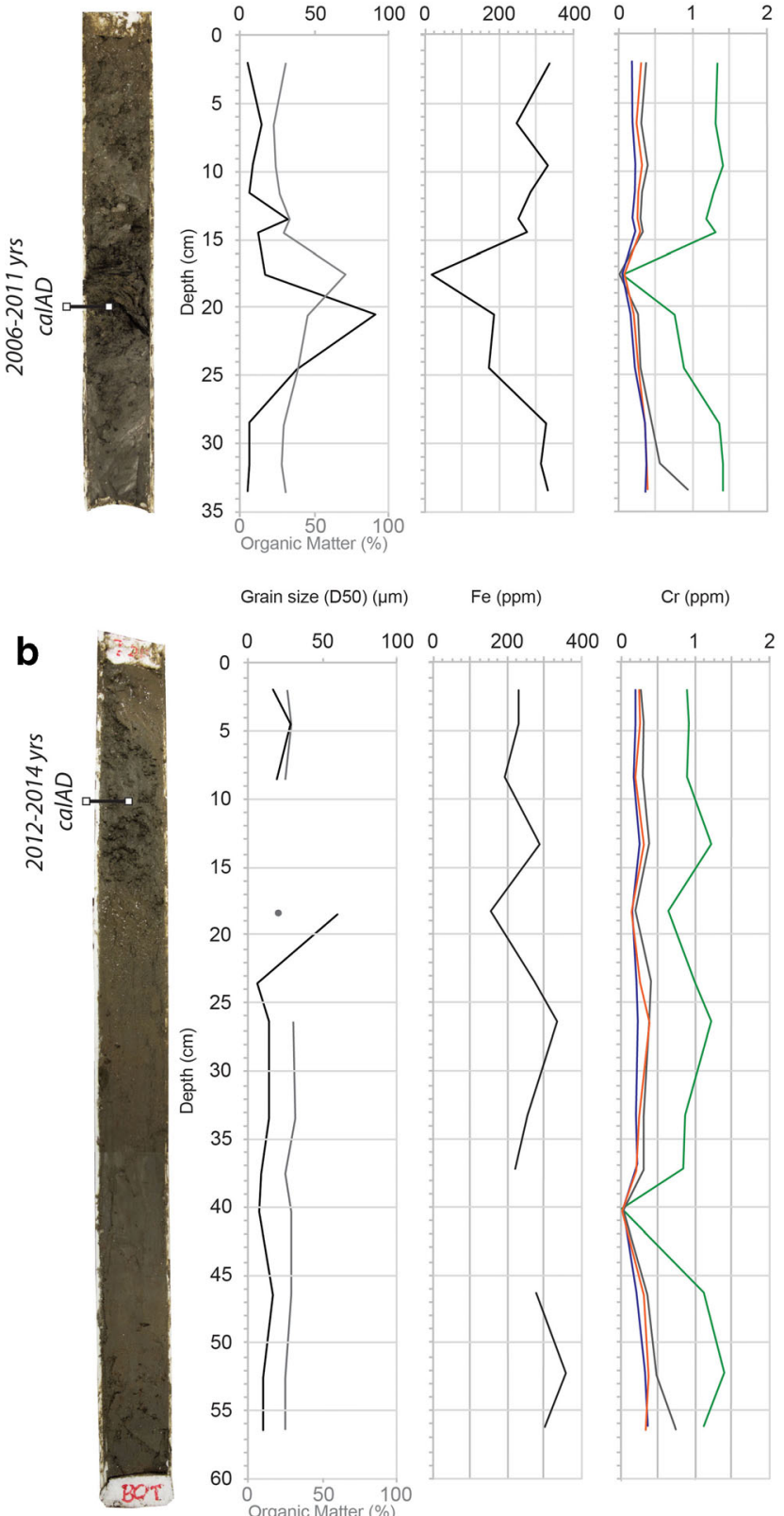

Fe (ppm)

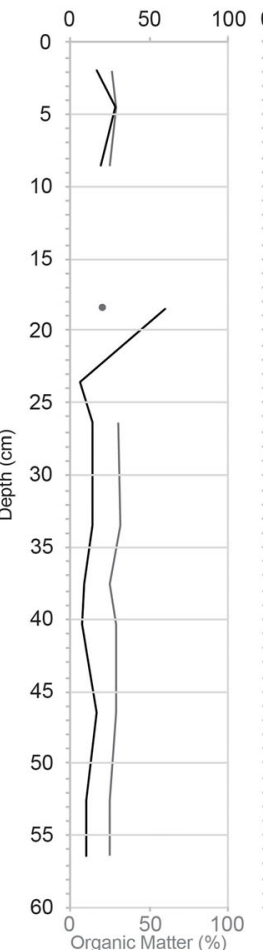

Cr (ppm)
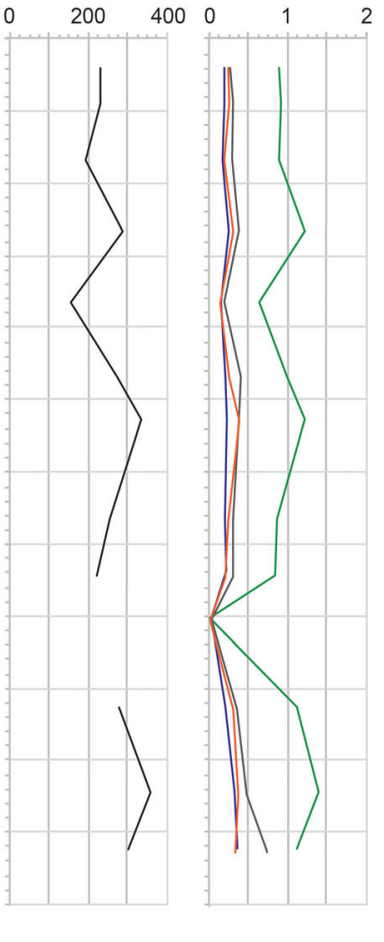

C

Grain size (D50) $(\mu \mathrm{m})$

$\mathrm{Fe}(\mathrm{ppm})$

Other metals (ppm)

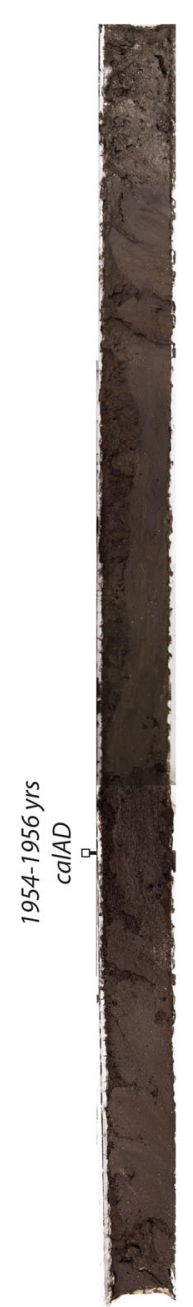

$\begin{array}{lll}0 & 200 \quad 400\end{array}$
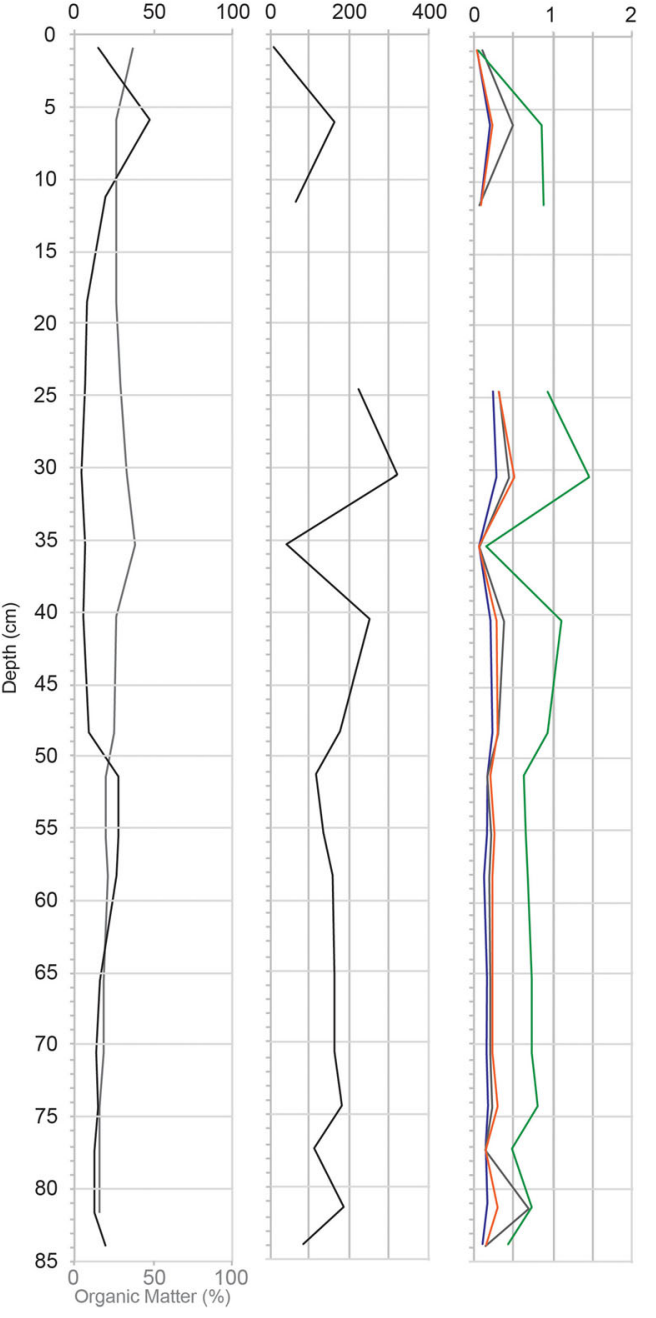

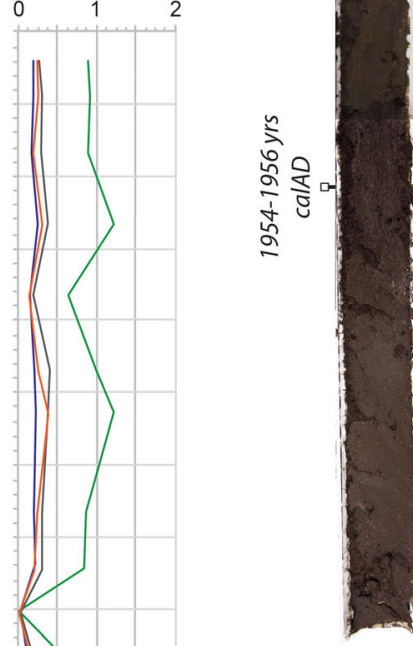

Fig. 3 Profiles of core 1 (a), core 3 (b), and core 7 (c) showing grain size, organic matter content, and distribution of Fe, Cr (green), Cu (orange), Zn (gray), and $\mathrm{Pb}$ (blue)

$1.30 \mathrm{mg} \mathrm{kg}^{-1}$, Fe increases from 15 to $275 \mathrm{mg} \mathrm{kg}^{-1}$, Cu increases from 0.08 to $0.29 \mathrm{mg} \mathrm{kg}^{-1}, \mathrm{Zn}$ increases from 0.02 to $0.34 \mathrm{mg} \mathrm{kg}^{-1}$, and $\mathrm{Pb}$ increases from 0.06 to $0.24 \mathrm{mg} \mathrm{kg}^{-1}$. The cross-plots of organic matter versus trace metals (Online Resources 1 of the Electronic Supplementary Material) show a clear linear correlation, whereby a decreasing OM content corresponds to a net increase in all the trace elements $\left(\mathrm{R}^{2}\right.$ of 0.8 and 0.94 for $\mathrm{Fe}$ and $\mathrm{Cr}$, respectively). There is no apparent correlation between grain size and metal contents, whereas $\mathrm{OM}$ and grain size are positively correlated (Online Resources 1 of the Electronic Supplementary Material).
Core 3 was collected ca. $600 \mathrm{~m}$ upstream from the embankment wall (Fig. 1d). This core shows a clear upper horizon with fluffy dark olive gray mud (ca. $20 \mathrm{~cm}$ ), a central part with olive gray to reddish green cohesive mud and a lower part (around $50 \mathrm{~cm}$ depth) made up of dark olive gray cohesive mud (Fig. 3b). The distribution of Fe shows large fluctuations with concentrations varying between ca. 155 and $358 \mathrm{mg} \mathrm{kg}^{-1}$ (Fig. 3b). Other trace metal profiles show similar vertical profiles with overall upward decreases in concentrations: 1.1 to $0.9 \mathrm{mg} \mathrm{kg}^{-1}$ for $\mathrm{Cr}, 0.33$ to $0.24 \mathrm{mg} \mathrm{kg}^{-1}$ for $\mathrm{Cu}, 0.74$ to $0.26 \mathrm{mg} \mathrm{kg}^{-1}$ for $\mathrm{Zn}$, and 0.37 to $0.21 \mathrm{mg} \mathrm{kg}^{-1}$ for $\mathrm{Pb}$. The 


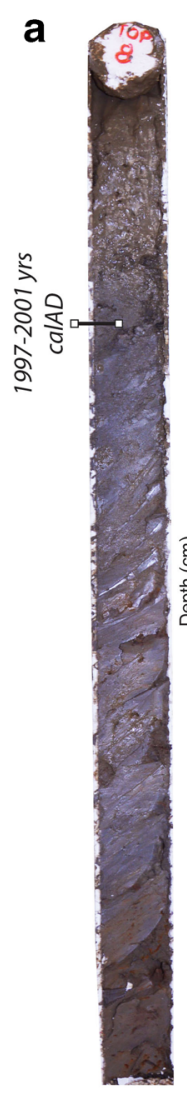

Grain size (D50) $(\mu \mathrm{m})$

Fe (ppm)

Other metals (ppm)

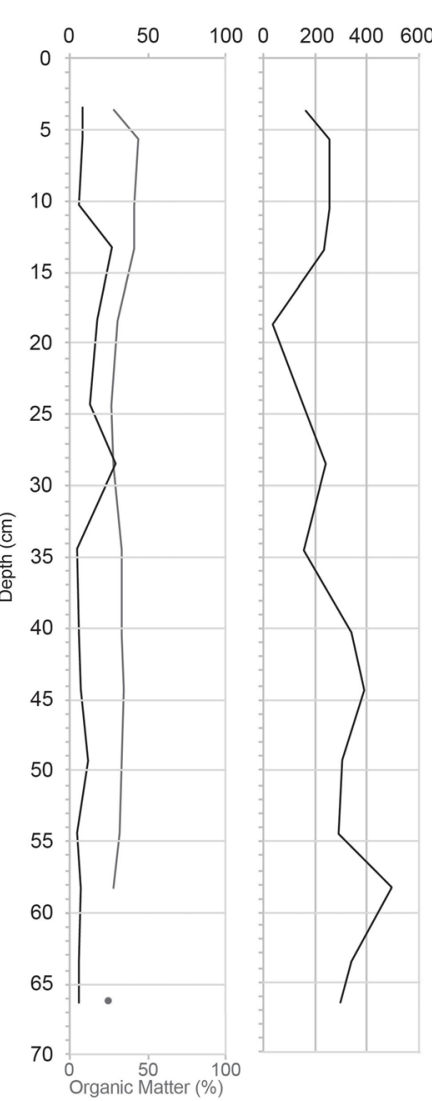

$\begin{array}{lll}0 & 1 & 2\end{array}$

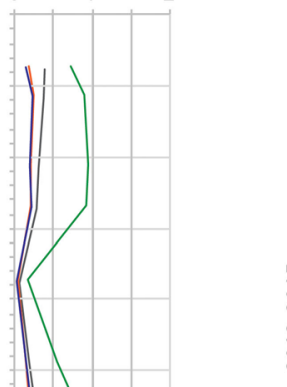

C

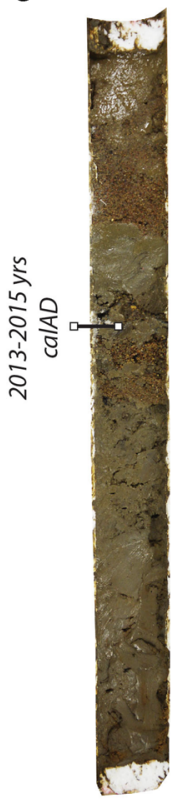

Fe (ppm)

Other metals (ppm)

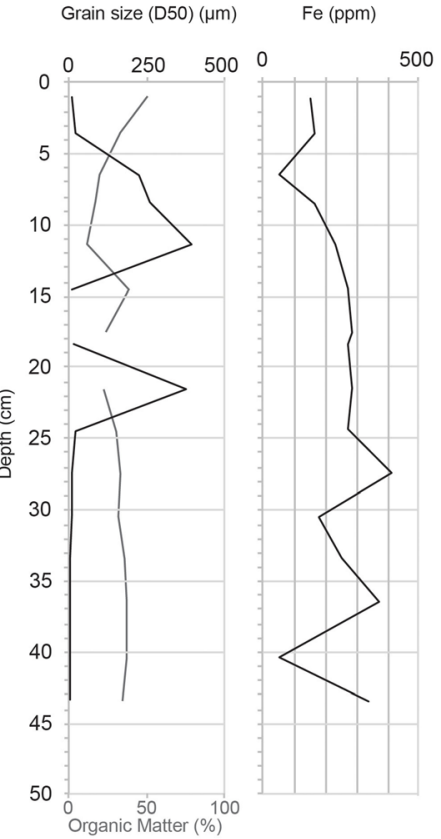

$\begin{array}{lll}0 & 1 & 2\end{array}$
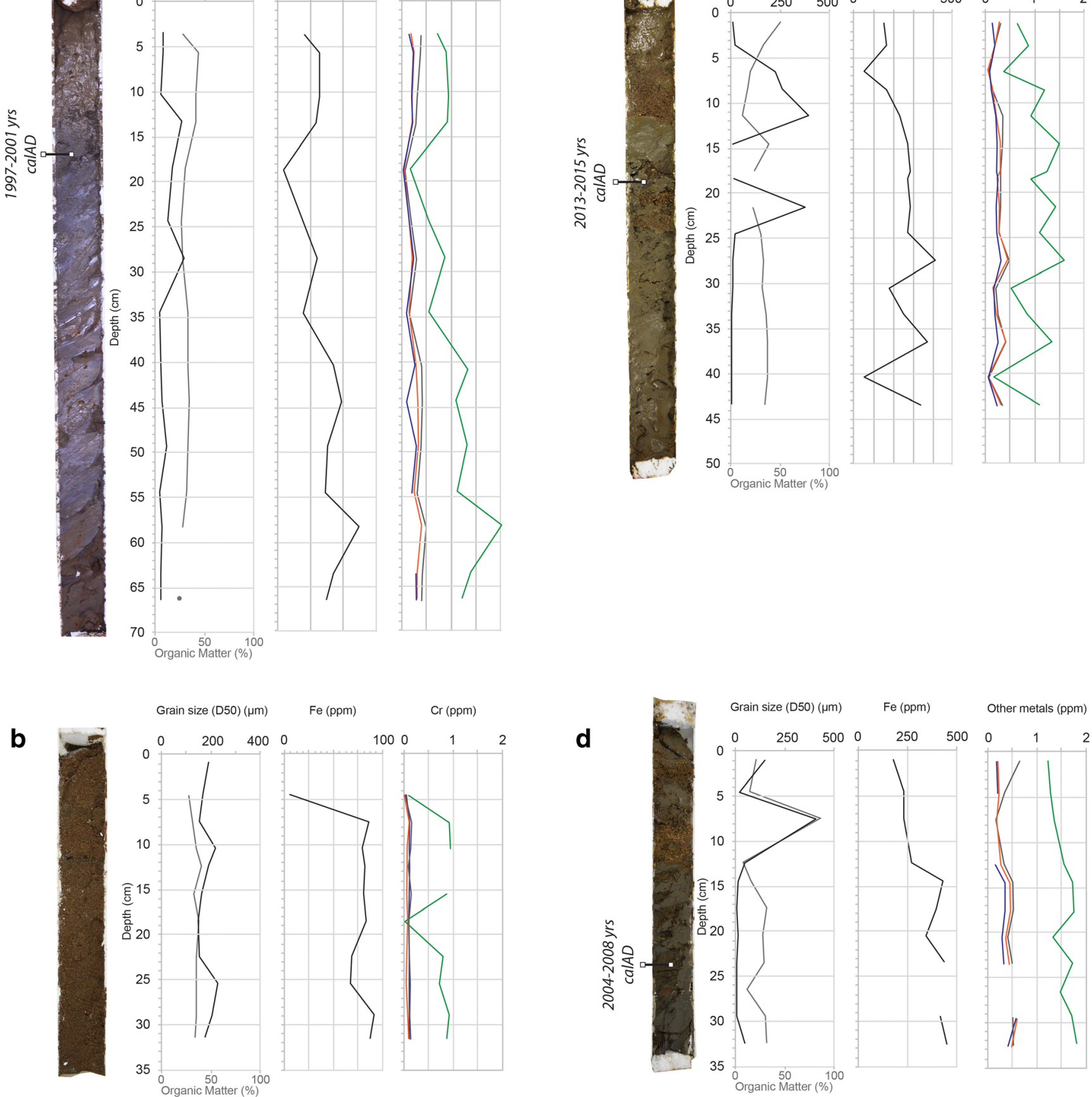

$\mathrm{Cr}(\mathrm{ppm})$
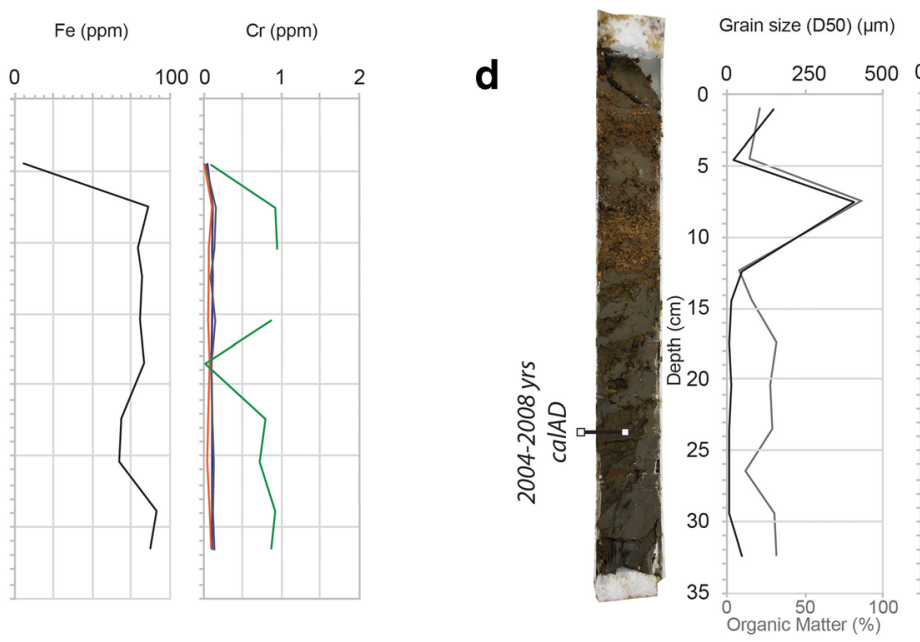

$\mathrm{Fe}(\mathrm{ppm})$

Other metals (ppm)
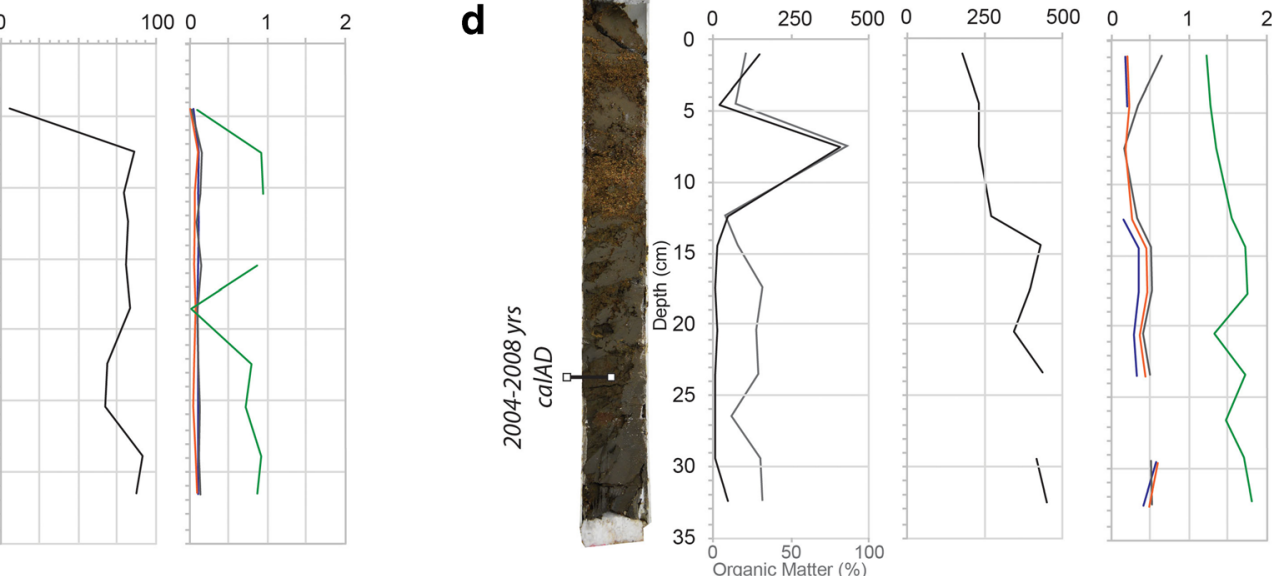

Fig. 4 Profiles of core 8 (a), core 9 (b), core 10 (c), and core 11 (d) showing grain size, organic matter content and distribution of $\mathrm{Fe}, \mathrm{Cr}$ (green), $\mathrm{Cu}$ (orange), $\mathrm{Zn}$ (gray), and $\mathrm{Pb}$ (blue)

profiles are characterized by two marked negative peaks at around $18 \mathrm{~cm}$ and a negative peak at ca. $40 \mathrm{~cm}$ (Fig. 3b).

Core 7 was collected ca. $400 \mathrm{~m}$ upstream from the embankment wall (Fig. 1d). This is the longer core collected in the Notwane Dam. Except for a 10-cm horizon of noncohesive silt between 50 and $60 \mathrm{~cm}$, the sediments are mainly very fine silt with OM content decreasing from 38 to $16 \%$ (Fig. 3c). The metal profiles show large fluctuations, especially Fe which varies from a few $\mathrm{mg} \mathrm{kg}^{-1}$ at the surface to $>400 \mathrm{mg} \mathrm{kg}^{-1}$ at $30 \mathrm{~cm}$ depth. The profiles of other metals show a more or less constant vertical distribution with two negative peaks of concentrations recorded at depths of $35 \mathrm{~cm}$ and $77 \mathrm{~cm}$ (Fig. 3c). There is no significant correlation between $\mathrm{OM}$ and metal contents and between grain size and metal contents in this core (Online Resources 1 of the Electronic Supplementary Material). 
Table 2 Average composition of the rock basement in the Notwane dam catchment. Dolostone: average composition of massive dolomite from Franchi (2018). Rhyolite: average massive rhyolite from Lowe (1995). Granite: average granophyric microgranite from Lowe (1995)

\begin{tabular}{llll}
\hline \multirow{2}{*}{ Element } & \multicolumn{2}{l}{ Concentration $(\mathrm{ppm})$} & \\
\cline { 2 - 4 } & Dolostone & Rhyolite & Granite \\
\hline $\mathrm{Fe}$ & $3200 / 0.57^{\mathrm{a}}$ & $4.59^{\mathrm{a}}$ & $2.40^{\mathrm{a}}$ \\
$\mathrm{Zn}$ & 4.8 & 130.2 & 46.1 \\
$\mathrm{Cu}$ & 1.3 & 3 & 1 \\
$\mathrm{Cr}$ & 2.6 & 3 & 6 \\
$\mathrm{~Pb}$ & 4.5 & - & - \\
\hline
\end{tabular}

${ }^{\mathrm{a}}$ In wt.\%

Core 8 was collected ca. $1 \mathrm{~km}$ upstream from the embankment wall (Fig. 1d). This core shows three distinct horizons with textures dominated by fine- and medium-grained silt (Fig. 4a). The metal profiles in core 8 show strongly variable concentrations (except for $\mathrm{Cu}$ and $\mathrm{Zn}$ ) with an overall increase with depth (Fig. 4a): Cr contents increase from 0.71 to $1.23 \mathrm{mg} \mathrm{kg}^{-1}$, Fe contents increase from 165 to $300 \mathrm{mg} \mathrm{kg}^{-1}$, $\mathrm{Cu}$ contents increase from 0.18 to $0.31 \mathrm{mg} \mathrm{kg}^{-1}$, and $\mathrm{Pb}$ contents increase from 0.15 to $0.30 \mathrm{mg} \mathrm{kg}^{-1}$. Particularly, a negative peak of all metals is found at ca. $18 \mathrm{~cm}$ and $35 \mathrm{~cm}$ depth, while the horizon at ca. $58 \mathrm{~cm}$ is characterized by an increase of all metal concentrations $\left(\mathrm{Fe}=495 \mathrm{mg} \mathrm{kg}^{-1} ; \mathrm{Zn}=0.48 \mathrm{mg} \mathrm{kg}^{-1}\right.$; $\mathrm{Cu}=0.39 \mathrm{mg} \mathrm{kg}^{-1} ; \mathrm{Cr}=2.04 \mathrm{mg} \mathrm{kg}^{-1} ; \mathrm{Pb}$ measurement is missing from this layer) (Fig. 4a). There is no significant correlation between OM contents and metal contents and between grain size and metal contents in this core (Online Resources 1 of the Electronic Supplementary Material).

Core 9 was collected ca. $900 \mathrm{~m}$ upstream from the embankment wall in front of the mouth of a small stream (Fig. 1d). This core is entirely made by fine to medium grained sand. The metal contents in the first $8 \mathrm{~cm}$ of the core are very low if compared to the lower part of the core with an average tenfold difference. The bottom part of the core, from ca. $10 \mathrm{~cm}$ to $32 \mathrm{~cm}$ depth, is characterized by linear profiles with average concentrations of $\mathrm{Fe}=46 \mathrm{mg} \mathrm{kg}^{-1}, \mathrm{Zn}=0.07 \mathrm{mg} \mathrm{kg}^{-1}, \mathrm{Cu}=$ $0.04 \mathrm{mg} \mathrm{kg}^{-1}$, and $\mathrm{Pb}=0.06 \mathrm{mg} \mathrm{kg}^{-1}$ (Fig. 4b). Only Cr profile shows a net decrease at ca. $18.5 \mathrm{~cm}$ depth (Fig. 4b). Fe, $\mathrm{Cu}$, and $\mathrm{Pb}$ show a positive correlation with the $\mathrm{OM}$ contents with low statistical significance $\left(\mathrm{R}^{2}\right.$ between 0.4 and 0.3 ; Online Resources 1 of the Electronic Supplementary Material) whereas $\mathrm{Zn}$ has a strong negative correlation with the OM content in this core $\left(\mathrm{R}^{2}=0.88\right)$. There is no correlation between grain size and metal contents (Online Resources 1 of the Electronic Supplementary Material).

Core 10 was collected ca. $800 \mathrm{~m}$ upstream from the embankment wall (Fig. 1d). This core can be subdivided in three different horizons: a lower horizon of greenish mud and two normal graded beds in the upper part of the core. The metal profiles show high variability that disappears once metal concentrations are normalized to the OM contents (Online Resources 1 of the Electronic Supplementary Material). The lowermost $35 \mathrm{~cm}$ of the core shows constant profiles with average values of $\mathrm{Fe}=84 \mathrm{mg} \mathrm{kg}^{-1}, \mathrm{Zn}=0.1 \mathrm{mg} \mathrm{kg}^{-1}, \mathrm{Cu}=$ $0.1 \mathrm{mg} \mathrm{kg}^{-1}, \mathrm{Cr}=0.34 \mathrm{mg} \mathrm{kg}^{-1}$, and $\mathrm{Pb}=0.07 \mathrm{mg} \mathrm{kg}^{-1}$. At ca. $12 \mathrm{~cm}$ depth, the concentrations of all the metals abruptly increase (Fig. 4c), only to decrease again in the topmost (ca. $7 \mathrm{~cm}$ ) sediments (average: $\mathrm{Cr}=0.2 \mathrm{mg} \mathrm{kg}^{-1}, \mathrm{Fe}=36 \mathrm{mg} \mathrm{kg}^{-1}$, $\left.\mathrm{Cu}=0.05 \mathrm{mg} \mathrm{kg}^{-1}, \mathrm{Zn}=0.05 \mathrm{mg} \mathrm{kg}^{-1}, \mathrm{~Pb}=0.04 \mathrm{mg} \mathrm{kg}^{-1}\right)$. Interestingly, the peak at $12 \mathrm{~cm}$ is only few centimeters above a horizon recording a sharp decrease of the OM content, from 37 to $11 \%$ and corresponds to a lag of medium to coarse sand (Fig. 4c). Otherwise, there is no significant correlation between OM and metal contents and between grain size and metal contents in this core (Online Resources 1 of the Electronic Supplementary Material).

Core 11 was collected near core 10 at ca. $800 \mathrm{~m}$ upstream from the embankment wall (Fig. 1d). This core shows three distinct horizons comparable with those described in core 10 (Fig. 4d). With the exception of $\mathrm{Zn}$, all the metal concentrations show a gradual decrease toward the top of the core: $\mathrm{Cr}$ concentrations decrease from 1.81 to $1.23 \mathrm{mg} \mathrm{kg}^{-1}$, Fe concentrations decrease from 455 to $177 \mathrm{mg} \mathrm{kg}^{-1}$, Cu concentrations decrease from 0.47 to $0.18 \mathrm{mg} \mathrm{kg}^{-1}, \mathrm{~Pb}$ concentrations
Table 3 Radiocarbon results, including sample code, depth, type of material analyzed, fraction modern carbon $\left(\mathrm{F}^{14} \mathrm{C}\right), \Delta^{14} \mathrm{C}(\%)$, calibrated age (calAD), and probability over the calAD

\begin{tabular}{|c|c|c|c|c|c|c|c|c|c|}
\hline Lab ID & $\begin{array}{l}\text { Core } \\
\text { ID }\end{array}$ & $\begin{array}{l}\text { Depth } \\
\text { (cm) }\end{array}$ & Material & F14 C & \pm & $\begin{array}{l}\Delta 14 \mathrm{C} \\
(\% \circ)\end{array}$ & \pm & calAD & $\begin{array}{l}\text { calAD } \\
\text { probability }\end{array}$ \\
\hline UOC-7655 & 1 & 19-20 & Plant debris & 1.061 & 0.0035 & 52.31 & 3.47 & 2006-2011 & $90.9 \%$ \\
\hline UOC-7656 & 3 & $11-15$ & Plant debris & 1.0395 & 0.0034 & 30.96 & 3.41 & 2012-2014 & a \\
\hline UOC-7657 & 7 & $54-59$ & Roots & 0.9965 & 0.0033 & -11.62 & 3.3 & 1954-1956 & $72.3 \%^{\mathrm{b}}$ \\
\hline UOC-7658 & 8 & $15-18$ & $\begin{array}{l}\text { Plant debris } \\
\quad \text { (seeds) }\end{array}$ & 1.1033 & 0.0036 & 94.31 & 3.61 & 1997-2001 & $90.9 \%$ \\
\hline UOC-7659 & 10 & $18-20$ & Plant debris & 1.0332 & 0.0034 & 24.76 & 3.38 & 2013-2015 & $\mathrm{a}$ \\
\hline UOC-7660 & 11 & $22-25$ & Plant debris & 1.0713 & 0.0036 & 62.54 & 3.53 & 2004-2008 & $84.2 \%$ \\
\hline
\end{tabular}

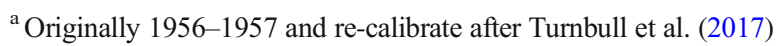

${ }^{\mathrm{b}}$ Seuss effect 


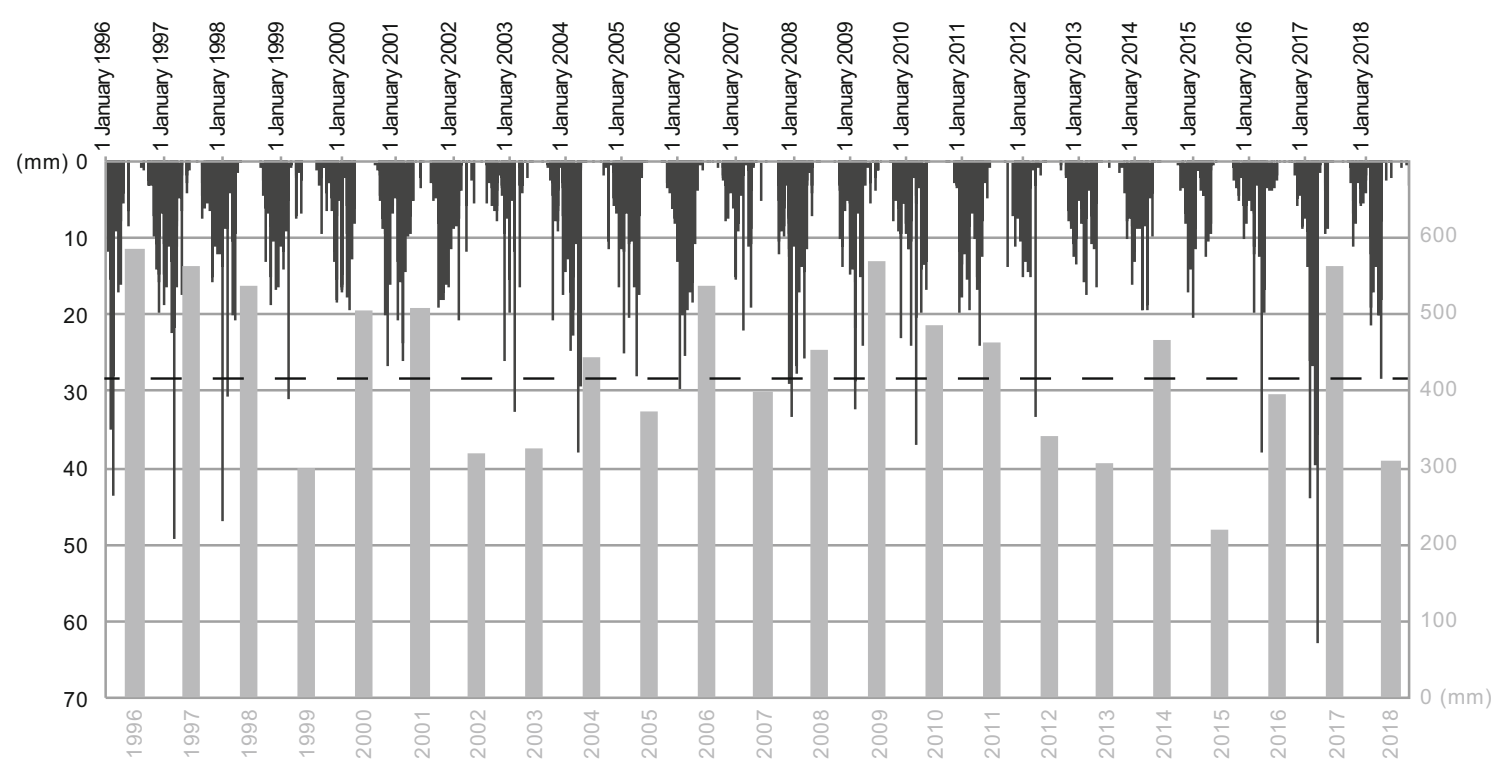

Fig. 5 Plot of the rainfall series in the Notwane River catchment from January 1996 to September 2018. The broken line indicates the average annual rainfall from CHIRPS dataset. Source: CHIRPS v2.0 Africa

decrease from 0.41 to $0.17 \mathrm{mg} \mathrm{kg}^{-1}$ (Fig. $4 \mathrm{~d}$ ). There is no significant correlation between $\mathrm{OM}$ and metal contents and between grain size and metal contents in this core (Online Resources 1 of the Electronic Supplementary Material).

\subsection{Radiometric age of the Notwane Dam sediments}

Radiocarbon analyses were carried out on six samples of sediments from the Notwane Dam with abundant plant debris (Table 3). One sample of mainly root fragments from core 7 was dated to around 1954-1956, pre-dating the construction of the dam. For this reason, this measurement is excluded from the dataset. The ages of the other samples fell between 1997 and 2001 and 2013 and 2015 (Table 3), which within the range of analytical error were consistent with the last three major flood events in 2001, 2011, and possibly 2016 (see below).

\subsection{Rainfall series and dam levels}

The total annual and daily rainfall time series for the Notwane River catchment show intense rains in the years 1996-1998 with single events well above $40 \mathrm{~mm}$ ( $44 \mathrm{~mm}$ on 11 February 1996, $49 \mathrm{~mm}$ on 5 March 1997, and $47 \mathrm{~mm}$ on 6 January 1998) which are comparable only to the main events of early 2017 when the cyclone Dineo brought $44 \mathrm{~mm}$ on 7 January 2017 and $60 \mathrm{~mm}$ on 20 February 2017 (Fig. 5). This means that over the 28 years of CHIRP records (1990-2018) rainfall events of over $40 \mathrm{~mm}$ in 1 day have a return period of 6 years, while events over $60 \mathrm{~mm}$ in 1 day have only been observed once, which makes a return period of over 28 years for the Dineo rainfall of the 20 February 2017. Interestingly, the years of recorded floods in Southern Africa, 2000 (Mozambican flood; e.g., Dyson and Van Heerden 2001), 2009 (e.g., De Groeve 2010), and 2011 (WMO statement on the status of the global climate 2012) are not characterized by short, high-intensity rainfall events (e.g., whereby the monthly average rainfall is exceeded) in Botswana (Fig. 5). Instead, it appears that the 2000,2009, and 2011 seasons are characterized by normal to higher-than-normal precipitation totals occurring over one or two rainy seasons (Fig. 5).

Figure 6 shows the daily rainfall series from the rain season of 2012 up until December 2017 plotted against the water levels in the Nnywane and Gaborone reservoirs. While Nnywane reservoir (Fig. 6a) replenished every year since 2014 between December and February, because of its small capacity and less use for water supply, Gaborone reservoir (Fig. 6b) showed a less regular trend. The Gaborone reservoir levels showed a regular decreasing trend until January-February 2016, when high rains resulted in rapid but partial replenishment of the reservoir. The following year, during Dineo cyclone in January and February 2017, the dam then reached its full capacity within a relatively short period of $/>$ time.

\subsection{Water quality data}

Water from the Notwane reservoir and the nearby borehole were collected across the period of time spanning from the aftermath of Dineo cyclone flood (April 2017) to May 2018 (Fig. 7a-d). The concentrations of $\mathrm{Cr}, \mathrm{Fe}, \mathrm{Ni}, \mathrm{Cu}, \mathrm{Zn}$, and $\mathrm{Pb}$ in the reservoir water showed an overall increase at the beginning of each rainfall event followed by rapid decrease in concentrations toward the end of, and after, the event (Fig. 7b, c). Groundwater from the nearby borehole shows similar patterns, but with overall lower metal concentrations and 


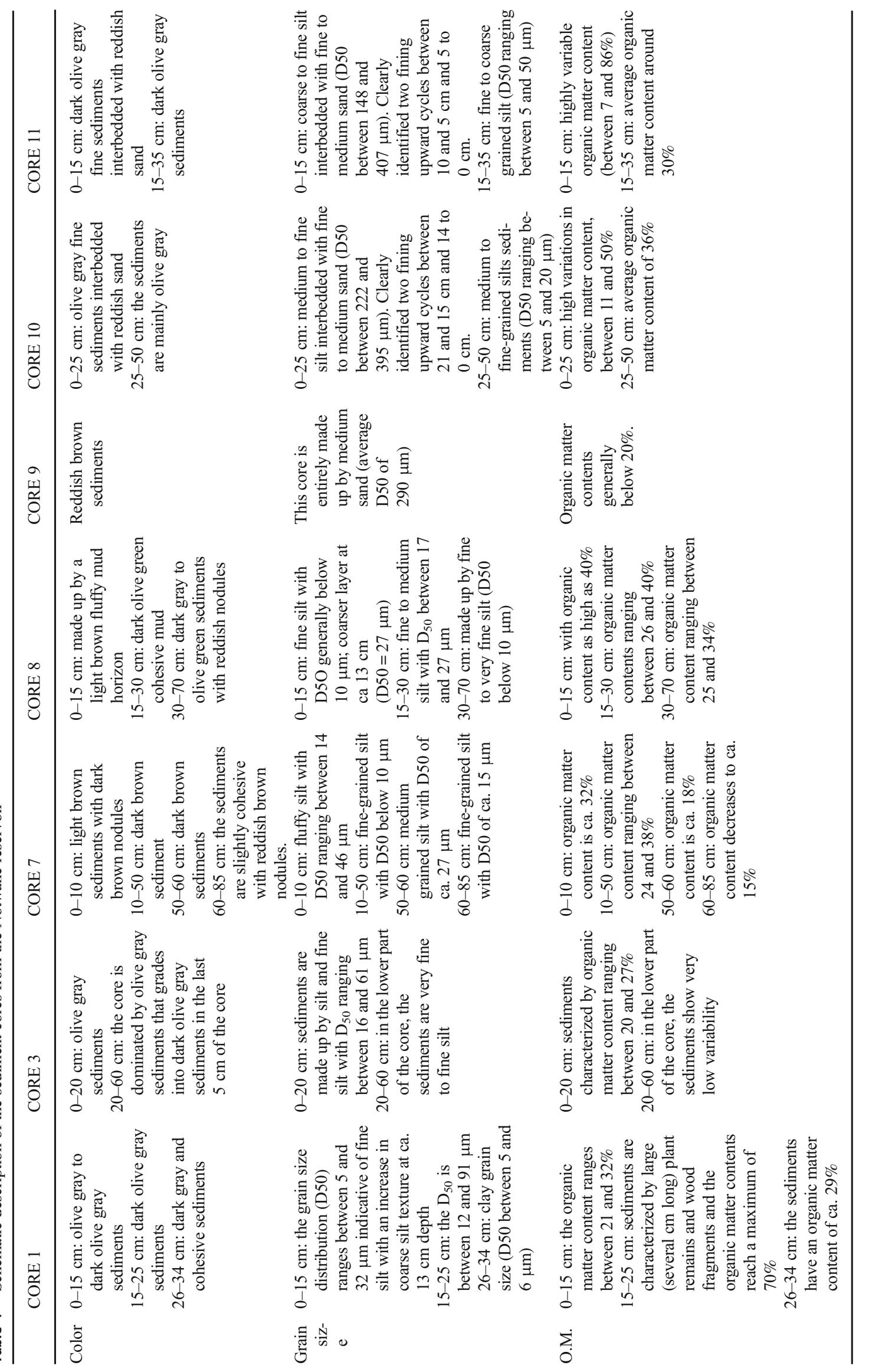



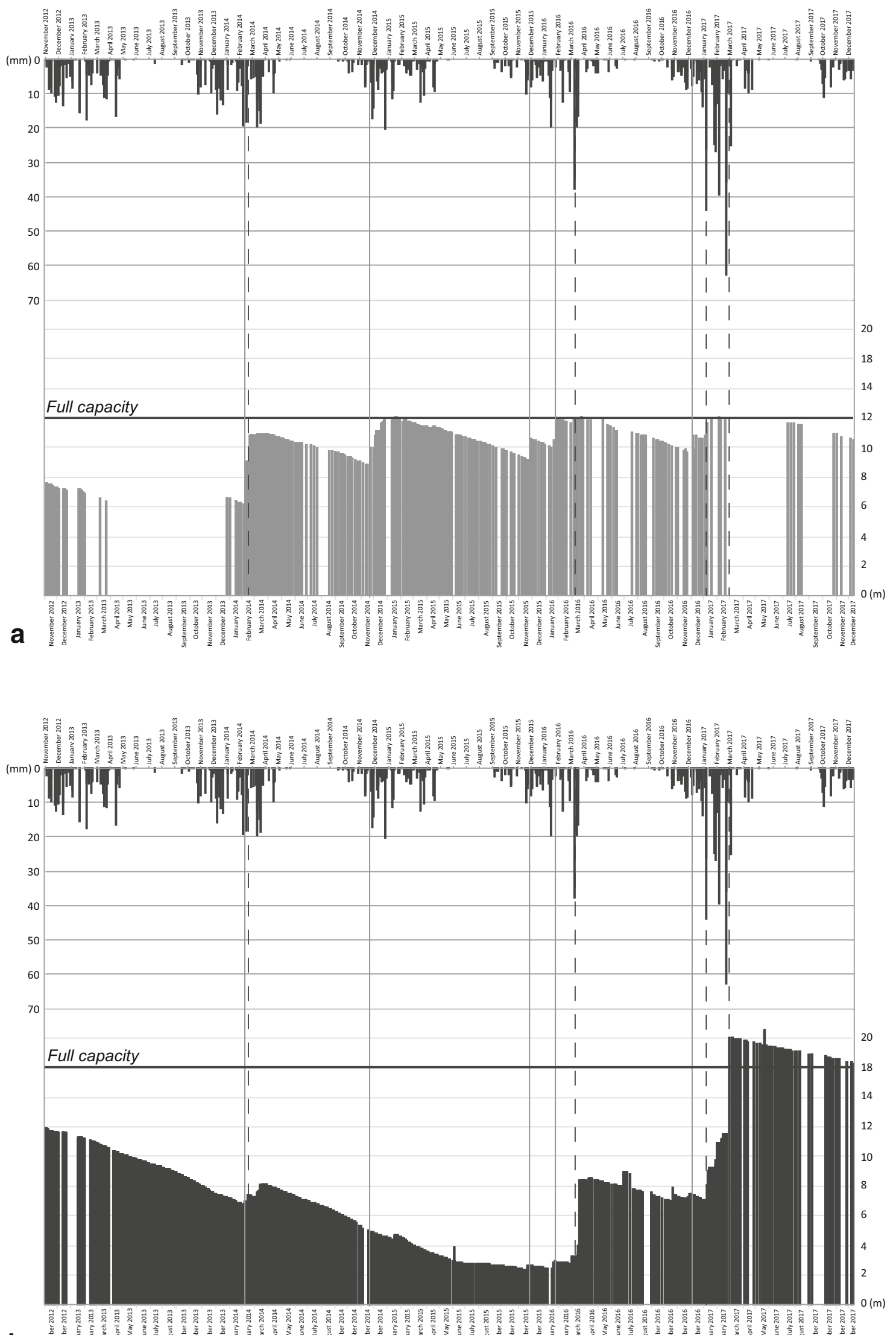

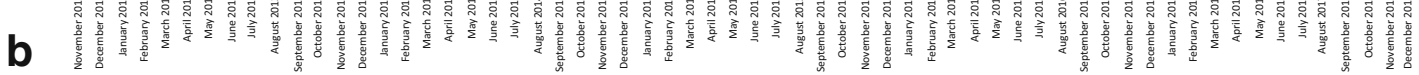


Fig. 6 Plot of the rainfall series in the Notwane River catchment from November 2012 to December 2017 against a Nnywane Dam (gray bars at the bottom) and $\mathbf{b}$ Gaborone Dam (black bars at the bottom) water levels. Source: CHIRPS v2.0 Africa and Department of Water and Sanitation Botswana

smoother variations, in particular a less marked decrease in concentration at the end and after the event (i.e., tailing) (Fig. 7d). In Fig. 7, the topmost part of core 10 has been correlated with the flood in early 2017 following Dineo cyclone (Fig. 7e, i.e., Couplet II in Fig. 8). The base of the coarse lag at ca. $12 \mathrm{~cm}$ depth consists of an erosive surface correlated with the heavy rains of February/March 2017 (Fig. 7). The finegrained sediments overlying the coarse lag (upper part of the couplet) record a general decrease of trace metals between July and August 2017 during the dry season followed by a general increase during the subsequent rainy season, in accordance with the water quality data from both the Notwane reservoir and the nearby borehole (Fig. 7).

\section{Discussion}

\subsection{Evidence for flood events in the Notwane reservoir sediments record}

Flood events deposit sediment couplets characterized by a basal lag comprising coarser sediment grading into an upper horizon of finer sediments. The coarse basal sediments, normally lighter in color, are deposited during the peak of the flood and their grain size can be linearly correlated with the magnitude of the floods (e.g., Foster et al. 2007; Zhao et al. 2017; Munoz et al. 2018). The upper, finer part of the flood couplets, represents sediment deposited from suspension during the later stages of the flood and

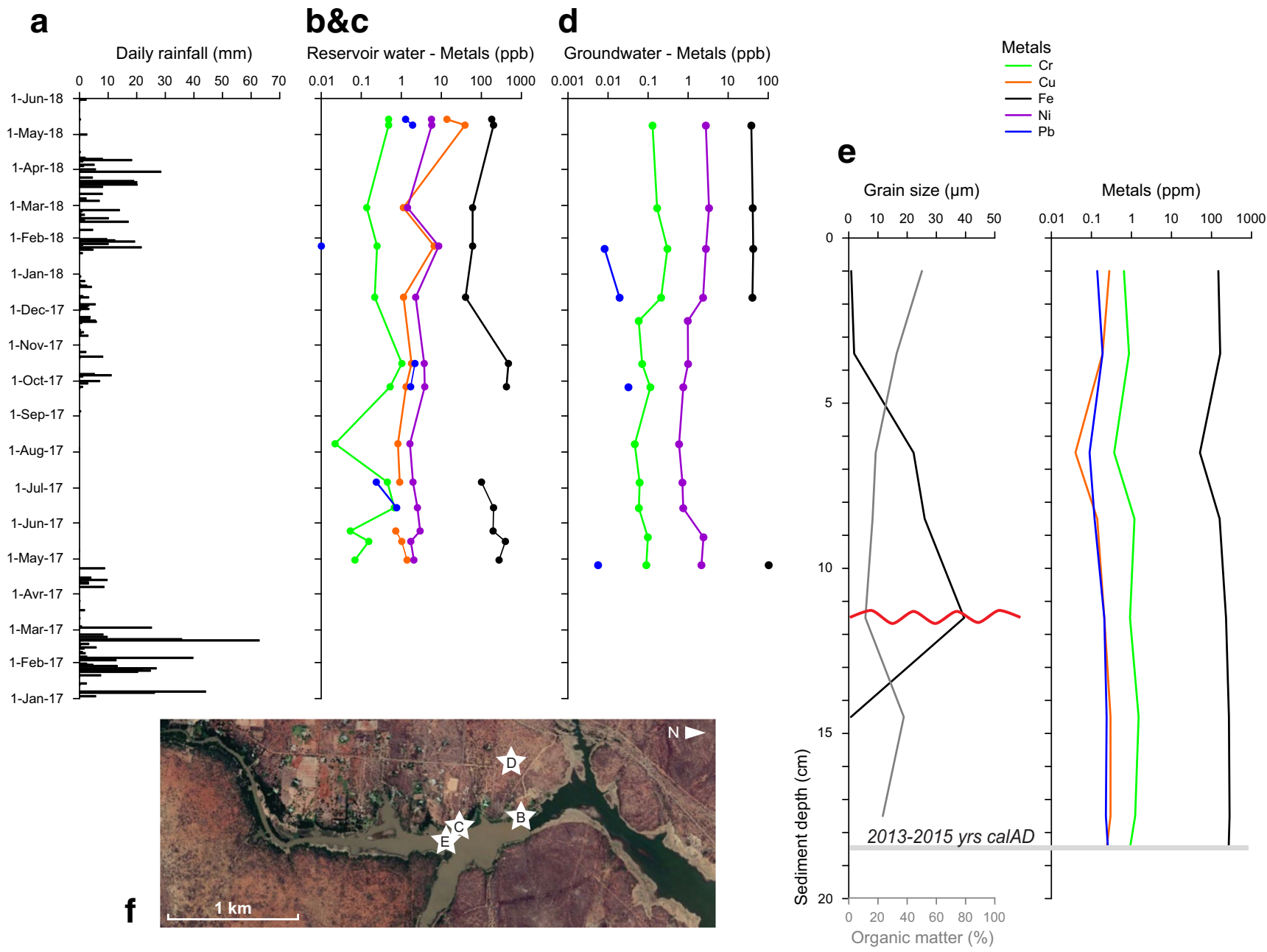

Fig. 7 Correlation charts of rainfall series (a), reservoir water quality (b, c), groundwater quality (d), and sediment profiles (e) in the Notwane Dam. The location of the sampling sites is shown in $\mathbf{f}$. In $\mathbf{b}-\mathbf{d}$, data gaps are measured metals below the analytical detection levels, therefore reflecting low values. The wavy red line in e shows the erosive base of couplet II (see Fig. 8); the thick gray line in $\mathbf{e}$ indicates the horizon dated with AMS ${ }^{14} \mathrm{C}$ 
J Soils Sediments (2020) 20:1632-1650

1645

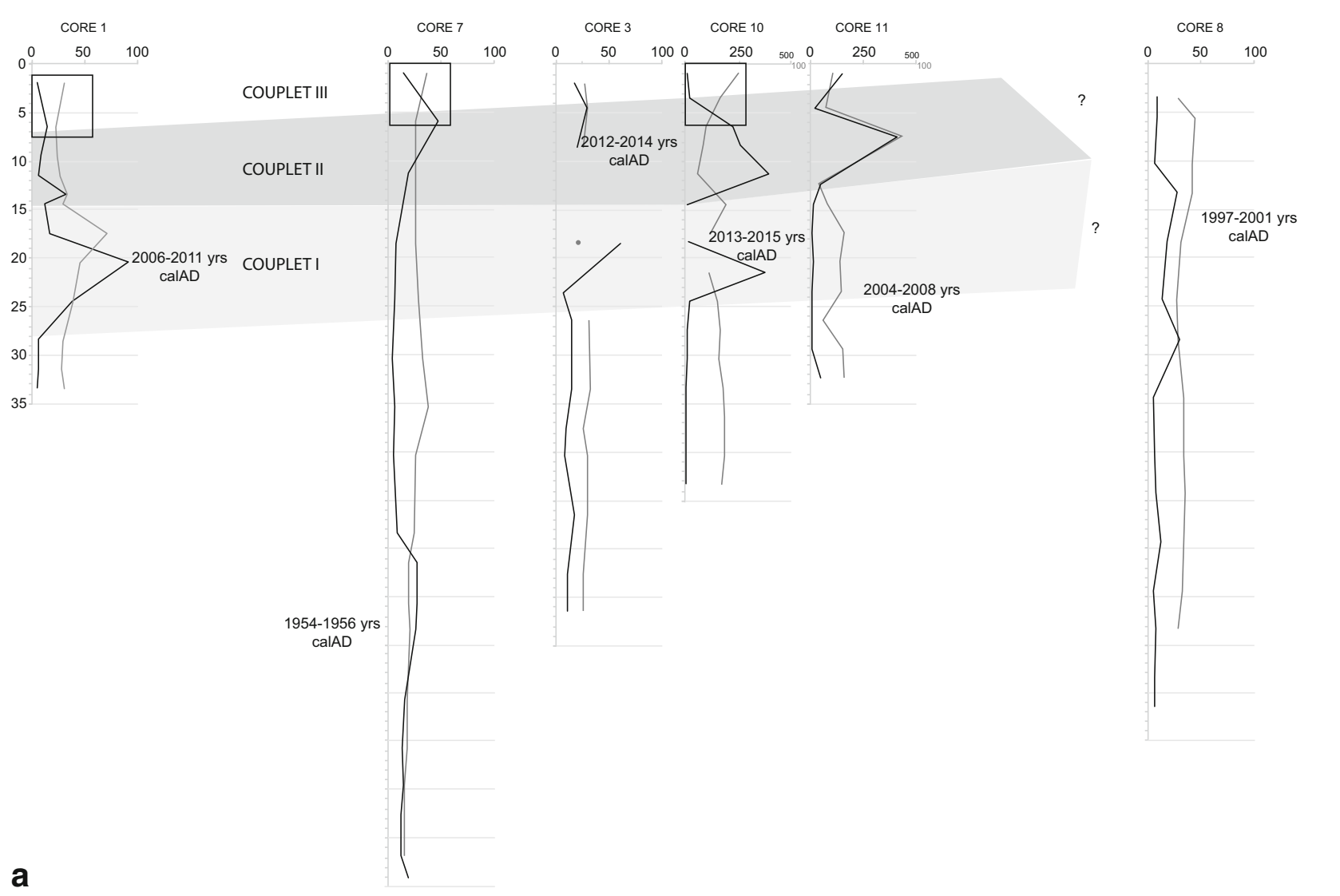

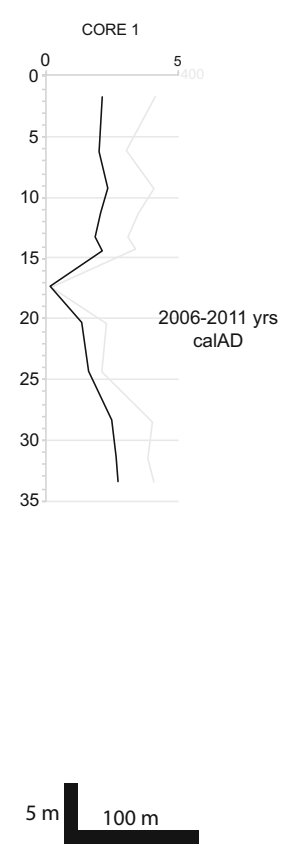

b

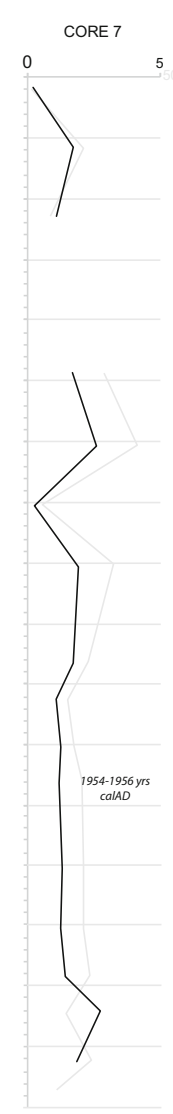

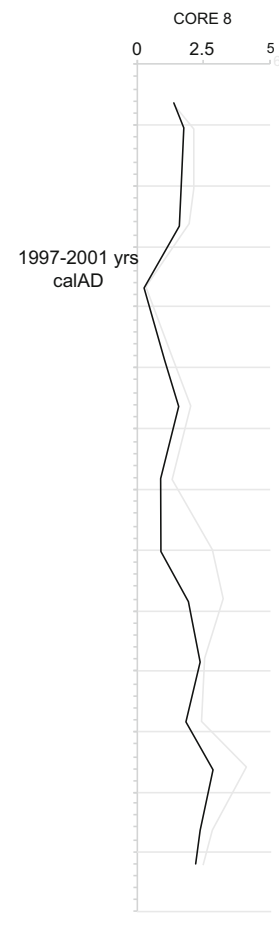

Springer 
4 Fig. 8 a Correlation chart of the grain size median (black lines) and organic matter (light gray line) content distribution in six cores from the Notwane Dam. The cores are aligned with distances from the dam embankment wall (left). b Correlation chart of the cumulative heavy metal contents without Fe (black lines) and Fe (light gray line) contents distribution in 6 cores from the Notwane Dam. The cores are aligned with distances from the dam embankment wall (left)

after the event (e.g., Zhao et al. 2017). The upper fine layer is frequently darker in color because of an overall increase in OM. The combination of the median of the grain size distribution within the couplets with trace metal distributions has been reported to be a successful approach in determining past flood events (Zhao et al. 2017; Munoz et al. 2018).

Sediment cores from the Notwane reservoir showed at least two couplets identified with normal graded beds characterized by a coarse to medium sand basal lag grading into mud (cf. Zhao et al. 2017) (Figs. 3, 4, and 8). These levels are interpreted as flood events and numbered I and II with a third and most superficial couplet (number III) poorly preserved in the record (Fig. 8). The first flood couplet (couplet I, Fig. 8) is found between 15 and $25 \mathrm{~cm}$ of depth and shows a sandy lag grading into fine silt with increasing OM contents. The second couplet (couplet II, Figs. 7 and 8) is found between 5 and $15 \mathrm{~cm}$ depth and is characterized by a ca. $3 \mathrm{~cm}$ sandy lag grading into olive gray silt and fine silt with increasing OM content (from $11 \%$ in the sand to $50 \%$ in the fine silt). The last couplet (couplet III, Fig. 8) is partially preserved only in core 7 and spans the topmost $5 \mathrm{~cm}$ of the sediments. The sandy lags at the base of these couplets correspond to strongly erosive events (erosional base) and are followed by an abrupt increase of OM and locally by horizons of plant fragments (Fig. 3a). These are plant remains that have been mobilized by the heavy rains at the peak of erosive potential.

In arid and semi-arid regions, the connectivity between surface water and groundwater is more prone to abrupt modification, i.e., a rapid increase in connectivity associated to floods induced by extreme rains as evidenced by groundwater level rise and similar chemistry (e.g., Ghazavi et al. 2012; Yang et al. 2017). This connectivity could be further enhanced if we consider that climate change is enhancing climate variability leading to more intense and frequent extreme events (Goode et al. 2012 and references therein), which in turn will lead to enhanced erosion and increase of the sediments yield into arid and semi-arid river catchments. Largerscale climate change impacts, however, often overlap with strongly heterogeneous conditions at the sub-catchment and catchment scale. For instance, Yang et al. (2017) have highlighted the high spatial variability of rainfall over a large catchment, demonstrating that the onset and termination of a meteorological drought can differ greatly between subcatchments and may lead to a substantial shift in the catchment rainfall-runoff relationship during prolonged droughts (see also Saft et al. 2015).

\subsection{Mobilization of heavy metals and potential pollution induced by extreme rain events}

In arid to semi-arid environments, physical remobilization during floods (and after storms in general) is probably more significant in determining the spatial distribution of heavy metals (Graf et al. 1991; Taylor and Kesterton 2002).

The aggregate heavy metal profiles and Fe profiles (Fig. 8b) show that flood couplet I is characterized by a negative peak in metal contents at the base with overall slight increase of metal contents during the deposition of finer materials after the flood (Fig. 8b). A direct correlation between fine-grained material and metal contents is common as clays, colloids, and organic particulates from sediments preferentially adsorb and coprecipitate soluble trace elements (e.g., Yao et al. 2015). Heavy metals and other contaminants, which are mainly bound to fine-grained material (surface area/volume ratio of a grain is inversely proportional to its size), pose an additional risk in arid environments where the finer sediments are also mobilized by the wind and are generally more abundant than in more humid settings (e.g., Taylor and Hudson-Edwards 2008).

Minor fluctuations in the heavy metal, OM, and grain size distribution profiles (Fig. 8) can be also interpreted as minor flood events (i.e., normal rainy seasons). In fact, low magnitude events can be associated with finer sediment and a higher OM content (Zhao et al. 2017). Goher et al. (2014) reported a relative increase of $\mathrm{Fe}, \mathrm{Cr}, \mathrm{Ni}$, and $\mathrm{Pb}$ contents prior to flood periods and argued that the heavy metals might be deposited during the water "stagnation" period that follows (and precedes) the flood event(s) as metals are bound to suspended matter that stays in suspension for a prolonged period after the flood momentum phase. From a similar arid catchment to the current study, Megnounif et al. (2007) have reported that 93\% of the annual suspended load carried by an ephemeral river is concentrated during storm events and subsequent floods. In arid to semi-arid environments, the main source of metals is therefore linked to intense soil erosion during the rainy season (Ghazavi et al. 2012; Goher et al. 2014). Similar results have been reported from the San Pedro River in Mexico, whereby sediments deposited during the dry season (Gómez-Álvarez et al. 2011) were enriched in heavy metals. Nevertheless, no unambiguous trends were found between grain size and metal contents in the studied samples (Fig. 8).

Overall trace metal contents are well below the TEC $(\mathrm{Cr}=$ 37.3, $\mathrm{Ni}=22.7, \mathrm{Cu}=35.7, \mathrm{Zn}=123, \mathrm{~Pb}=35 \mathrm{mg} \mathrm{kg}^{-1}$ ) and PEC $(\mathrm{Cr}=90, \mathrm{Ni}=48.6, \mathrm{Cu}=197, \mathrm{Zn}=315, \mathrm{~Pb}=$ $91.3 \mathrm{mg} \mathrm{kg}^{-1}$ ) reported in the SQGs by MacDonald et al. (2000), revealing that the floods did not contribute to input levels for this group of contaminants in the reservoir sediments to a degree that poses a threat to human health. Accordingly, $I_{\text {geo }}$ show highly negative values (Online Resources 2 of the Electronic Supplementary Material) revealing no enrichment of heavy metal contents compared to the calculated background 
(dolostone + granitoids rocks) and therefore the absence of contamination (all indexes fall within class 0 with $\mathrm{I}_{\mathrm{geo}}<0$ ).

\subsection{Correlation of the extreme events with the sedimentary record in the Notwane reservoir}

The ability to identify and quantify effects of heavy rains and floods from sediment records in a particular catchment depends upon the degree of correlation between the sedimentary record and existing hydrological data (Figs. 5, 6, and 7). The Gaborone district was struck by floods in 2001 and 2017 (Statistics Botswana 2018; Toteng 2018), and in early 2011, the northern, central, and southern regions of Botswana reported extreme rainfall resulting in the country's major dams being filled to capacity (Statistics Botswana 2018). Other arid and semi-arid areas of the southern hemisphere such as southeastern Australia have recorded high and non-seasonal late spring/summer rainfall induced by a strong La Niña event in early 2010 (Yang et al. 2017).

The rainfall series (Fig. 5) show that in a single event, on the 16th of February 2010, the study area received ca. $40 \mathrm{~mm}$ of rain, which correspond to more than half the average amount of rain expected for an average February (cf. Mengistu Tsidu 2016). This exceptional precipitation, in such a short period of time, would have triggered a flood caused by enhanced surface runoff which would have replenished the reservoirs along with depositing a flood couplet, as observed for recent $>40 \mathrm{~mm}$ rainfall events (i.e., 2016 and 2017). As radiocarbon ages do not unambiguously point toward 2010/ 2011 events, it is possible that the flood couplets identified in the Notwane reservoir are related to previous events that occurred in 2000/2001 (e.g., Dyson and Van Heerden 2001), 2009 (e.g., De Groeve 2010), or the late events of 2016 and early 2017 (this study). The latter scenario would be in agreement with the levels of nearby Nnywane and Gaborone reservoirs that showed peaks of water inflow in March 2016 and then again in January 2017 (Fig. 6).

As shown in Fig. 6, the replenishment of reservoirs within the same catchment can be asynchronous. This is because they are fed by the entire upstream catchment area, and reservoirs with different size, located in different areas of the catchment, might be affected by both local and regional flood events. Regional floods can be buffered by a series of dams with energy of the water decreasing downstream with direct effects on the sediment yield. The reservoir levels in the study area, for instance, reflect a buffering effect exerted by the Nnywane reservoir on the Gaborone reservoir whereby the first one (upstream) is replenished cyclically after every rain season, whereas the Gaborone reservoir (downstream) is only replenished during high rainfall year and flood periods (Fig. 6). Insignificant replenishment of Gaborone reservoir during low rainfall years can be explained by upstream interception of minor floods by Nnywane reservoir (and other small dams located on Gaborone Dam contributing streams including the Notwane reservoir). Similar effects have been recorded during the rainy season of 2015 when all the rain was intercepted by the Notwane reservoir, which has been filled to capacity, while the Gaborone reservoir was reaching its historical minimum (Water Utilities Corporation, Pers. Comm. 2019). The reduced sediment availability, induced by a buffering effect from other dams (i.e., Nnywane reservoir, Fig. 1), may lead to missing flood couplets or minor fluctuations in the sedimentary record (cf. Munoz et al. 2018).

The two major events in March 2016 and January/March 2017 (Fig. 5), which rapidly overtopped small upstream dams, brought large volumes of water into the Gaborone reservoir (Fig. 6). These two events might therefore be reasonably correlated with the couplets I and II found within the sediments of the Notwane reservoir (Fig. 8). Nevertheless, the radiometric carbon dates obtained from plant remains from the Notwane sediments show ages of 2006-2011, 2012-2014, and 2013-2015 (Table 3; Figs. 7 and 8), reflecting events more recent than 2000/2001 but still preceding the 2016 rain season. This imprecision in temporal reconstruction might be explained by the lack of more regionally specific atmospheric ${ }^{14} \mathrm{C}$ reservoir data used to determine postbomb carbon radiometric ages (see Sect. 3) and by the erosive nature of floods that erode sediments from the reservoirs. In the case of extreme flooding, in fact, the most recent event overcomes the dam impoundment and erodes rather than deposits (e.g., Zhao et al. 2017). To this extent, it is worth noting that before the main flood event of March 2017, the Notwane reservoir was already filled to capacity and for this reason, the event might not be preserved in the sediment record (Gaborone reservoir was at full capacity since January 2017; Fig. 6). It is therefore likely that the water over-spilt the dam and eroded sediments in the center of the reservoir (in what was the thalwegs of the Notwane River before impoundment). This would also explain the lack of lateral continuity of the flood couplets identified in the Notwane reservoir records (Fig. 8).

As part of an extensive monitoring network in the Notwane catchment, surface water and groundwater quality were analyzed for a period spanning between April 2017 and June 2018. Particularly, water quality data from the Notwane reservoir and a nearby borehole (Fig. 1) were correlated with rainfall series and sediment profiles (Fig. 7). The surface water quality data showed uneven patterns, also due to methodological issues (i.e., irregular sampling), but it is clear that the concentration of most of the trace metals analyzed increased after peaks of rainfall (Fig. 7a-c). Similar patterns, although smoother, were observed in groundwater (Fig. 7d). Using date of collection of the core (19 February 2018) and the radiometric age of OM found at $18 \mathrm{~cm}$ depth (Fig. 7e), we were able to correlate the profiles of core 10 with the rainfall series and the water quality data. In particular, we considered the presence of a depositional hiatus (erosive surface) at the base of the coarse lag in core 10 (red line in Fig. 7e) corresponding to the erosion 
induced by the onset of the flood of February/March 2017. The metal contents decreased toward the top of the core only to increase once again in the topmost $5 \mathrm{~cm}$ of the core where a peak in OM was recorded (Fig. 7e). The flood, therefore, appeared to have mobilized trace elements through transport in surface water and accumulation in sediment during their deposition, although it has not contributed to significant levels of pollution of the dam sediments as indicated by the low $\mathrm{I}_{\mathrm{geo}}$ values (Online Resources 2 of the Electronic Supplementary Material). The relationship between contaminant in sediment and in groundwater is not as straightforward and requires further investigation to highlight whether the reservoir exerts a control on contaminant levels in groundwater, i.e., through recharge or the other way around, i.e., through groundwater discharge. Either way, the overall relative agreement between temporal patterns of metal concentration in sediments, reservoir water, and groundwater, for the 1.5-year study period after Dineo cyclone, would confirm the ubiquitous nature of contaminant migration within the studied area and further suggests the potential of using sediment records as proxies to reconstitute pass contaminations.

This project demonstrated that our capacity of pinpointing effects of recent floods is not affected by the size of the study area. However, challenges remain with regard to the ability to accurately correlate sediments with meteorological and hydrological data at short time scales. There might be potential issues with time lags, but the outcomes of this project suggest that a main factor to consider is the ephemeral nature of rivers and river network disconnectedness because of the various different reservoirs in arid to semi-arid catchments. Both of these translate into a discontinuous sedimentary record. These regions are characterized by extreme climate variability and are subject to droughts and heavy, discontinuous rainfall periods often followed by floods (Bisantino et al. 2011; Al-Taani et al. 2015). It is paramount to avoid gaps in sampling of hydrometric and meteorological data to ensure same or similar detail in water quantity and quality on the one hand and sediment records the other. Only then correlations and potential time lags can be appropriately correlated. To this extent, an estimate of the sedimentation rate is important; a sediments trap might help provide an estimate of the sediment yield within the reservoir throughout the year allowing for less uncertainty in the correlation with the time series.

Sediment profiles must therefore be coupled with rainfall data and, where possible, reservoir water levels. In arid environments, where a reservoir can by dried up for long periods, the sediment distribution within these reservoirs might not be the same as identified in more humid environments. When more than one dam is present within the catchment, it becomes crucial to understand the buffering effect exerted by upstream dams; we have seen how in periods of normal rains, the peak of rainfall was enough to fill the Notwane reservoir but not to increase the level of that of Gaborone. The reduced sediment availability, induced by a buffering effect from other dams, may lead to missing flood couplets or minor fluctuations in the sedimentary record. To fully appreciate the effects of floods and heavy rain in the basin, a record representative of the whole catchment is essential.

When the goal is to assess amount of contamination during flood and/or drought, the sample preparation has to consider the contribution from diverse organic and mineral matrices; for this reason, it is preferable to use a sequential leaching that can discriminate among ready available pollutants and pollutants bound to oxides and other mineral phases. A weak acid leaching, like the one adopted for this study, might not highlight the partitioning effects due to different behaviors of metals.

\section{Conclusions}

For the first time, this work presented a multi-proxy approach of the study of effects of floods and droughts on the sediments from artificial dams in an arid to semi-arid catchment. The study of sediments from the Notwane reservoir in Botswana has provided insights into decadal trends in sediment input into regional reservoirs and correlations between floods, sediment yields, and metal distributions. In general, in arid to semi-arid environments, intense precipitations after prolonged drought generate strong surface runoff that can remove large amounts of soil. The effects of extreme precipitation are exacerbated by prolonged drought during which the already scarce vegetation cover is further reduced, weakening the soil strength and leading to gully and sheet erosion resulting during the subsequent wet periods.

Here, the timing and magnitude of alternating droughts and floods was identified, and horizons were characterized for their OM and clastic material contents. The sedimentary record of Notwane reservoir clearly preserved flood couplets in the first $30 \mathrm{~cm}$ of sediments. The joint interpretation of radiocarbon ages and analysis of rainfall series and dam levels suggested that these couplets may refer to the heavy rains of 2016 and 2017. The combination of radiometric age, rainfall series, and reservoir levels was not able to clearly detect the floods that struck other parts in southern Africa in 2000, 2009, and 2011.

The reservoir levels of nearby Nnywane and Gaborone reservoirs have demonstrated that the two reservoirs are not replenished by the same events. This highlights the importance of local hydroclimatic events in the study of semi-arid basing physiography. The comparison of data from the Nnywane and Notwane reservoirs (and Gaborone reservoir as consequence) shows that small dams upstream exert a buffering effect intercepting minor floods so that larger downstream dams only record large floods. 
The sediments of the Notwane reservoir showed heavy metal concentrations well below the SQGs which fell in the $I_{\text {geo }}$ class 0 coincident with no contamination. Surface water and groundwater quality data showed a peak of trace metals during major rains and subsequent decrease, which appeared in relative agreement with the observed vertical fluctuation in sediments at the short time scale we considered. It is reasonable to assume that a sequential leaching of the sediments would have highlighted an eventual correlation between readily available metals within the sediments and water quality data, but there might be delays in such correlations. More accurate sediment dating and correlations on longer monitoring periods are necessary to confirm this.

In conclusion, the study of sediments from reservoirs in arid to semi-arid environments can contribute to the reconstruction of flood events and contaminant transport but the effects of other dams in the upstream area must be accounted for. Sediments, as archives of past flood and drought cycles, can contribute to a better understanding of flood events and contribute toward the management of water resources in a context of increasing hydroclimatic extremes.

Acknowledgments The authors would like to thank the Editor and two anonymous reviewers for their comments and suggestions which have contributed to improve the quality of this paper.

The authors would like to thank all the BIUST students that took part in one or more field campaigns in the Notwane river catchment; their work and interests were remarkable. Thanks are due to Trust Manyiwa (BIUST) for the assistance with grain size and OM analyses and to Serwalo M. Mokgosi (BIUST) for assistance with the MP-AES measurements of sediment materials. We would like to thank the staff at the University of Aberdeen laboratory (Michael McGibbon) for assistance with the water quality analyses.

Funding information This research was funded by the UK Natural Environment Research Council NERC Urgency grant NE/R002568/1 (PULA Project).

Open Access This article is distributed under the terms of the Creative Commons Attribution 4.0 International License (http:// creativecommons.org/licenses/by/4.0/), which permits unrestricted use, distribution, and reproduction in any medium, provided you give appropriate credit to the original author(s) and the source, provide a link to the Creative Commons license, and indicate if changes were made.

\section{References}

Alemaw BF, Keaitse E, Chaoka T (2016) Management of water supply reservoirs under uncertainties in arid and urbanized environments. J Water Resour Protec 8:990-1009

Al-Taani AA, Batayneh AT, El-Radaideh N, Ghrefat H, Zumlot T, AlRawabdeh AM, Al-Momani T, Taani A (2015) Spatial distribution and pollution assessment of trace metals in surface sediments of Ziqlab reservoir, Jordan. Environ Monit Assess 187:1-14
Bisantino T, Gentile F, Trisorio Liuzzi G (2011) Continuous monitoring of suspended sediment load in semi-arid environments. In: Ginsberg SS (ed) Sediment transport. InTech Open, Rijeka, p 295

Bryant LD, Hsu-Kim H, Gantzer PA, Little JC (2011) Solving the problem at the source: controlling Mn release at the sediment-water interface via hypolimnetic oxygenation. Water Res 45:6381-6392. https://doi.org/10.1016/j.watres.2011.09.030.

Crann CA, Murseli S, St-Jean G, Zhao X, Clark ID, Kieser WE (2017) First status report on radiocarbon sample preparation at the A.E. Lalonde AMS Laboratory (Ottawa, Canada). Radiocarbon 59:695-704

De Groeve T (2010) Flood monitoring and mapping using passive microwave remote sensing in Namibia. Geomat Nat Hazard Risk 1:19-35

Dunbar JA, Allen PM, Bennett SJ (2010) Effect of multiyear drought on upland sediment yield and subsequent impacts on flood control reservoir storage. Water Resour Res 46:W05526

Dyson LL, Van Heerden J (2001) The heavy rainfall and floods over the northeastern interior of South Africa during February 2000. S Afr J Sci 97:80-86

El Azhari A, Rhoujjati A, El Hachimi ML (2016) Assessment of heavy metals and arsenic contamination in the sediments of the Moulouya River and the Hassan II dam downstream of the abandoned mine Zeïda (High Moulouya, Morocco). J Afr Earth Sci 119:279-288

Farkas A, Erratico C, Viganò L (2007) Assessment of the environmental significance of heavy metal pollution in surficial sediments of the River Po.Chemosphere 68: 761-768

Foster IDL, Boardman J, Keay-Bright J (2007) Sediment tracing and environmental history for two small catchments, Karoo uplands, South Africa. Geomorphology 90:126-143

Foster IDL, Rowntree KM, Boardman J, Mighall TM (2012) Changing sediment yield and sediment dynamics in the Karoo uplands, South Africa; post-European impacts. Land Degrad Dev 23:508-522

Franchi F (2018) Petrographic and geochemical characterization of the Lower Transvaal Supergroup stromatolitic dolostones (Kanye Basin, Botswana). Precambrian Res 310:93-113

Franchi F, Mapeo RBM (2019) Evolution of an Archaean intracratonic basin: a review of the Transvaal Supergroup lithostratigraphy in Botswana. Earth-Sci Rev 191:273-290

Ghazavi R, Vali AB, Eslamian S (2012) Impact of flood spreading on groundwater level variation and groundwater quality in an arid environment. Water Resour Manag 26:1651-1663

Goher ME, Farhat HI, Abdo MH, Salem SG (2014) Metal pollution assessment in the surface sediment of Lake Nasser, Egypt. Egypt J Aquat Res 40:213-224

Goode J R, Luce C H, Buffington J M (2012) Enhanced sediment delivery in a changing climate in semi-arid mountain basins: Implications for water resource management and aquatic habitat in the northern Rocky Mountains. Geomorphology 139-140:1-15

Gómez-Álvarez A, Valenzuela-García JL, Meza-Figueroa D, de la OVillanueva M, Ramírez-Hernández J, Almendariz-Tapia J, PérezSegura E (2011) Impact of mining activities on sediments in a semi-arid environment: San Pedro River, Sonora, Mexico. Appl Geochem 26:2101-2112

Graf WL, Clark SL, Kammerer MT, Lehman T, Randall K, Schroeder TR (1991) Geomorphology of heavy metals in the sediments of Queen Creek, Arizona, USA. Catena 18:567-582

He ZL, Yang XE, Stoffella PJ (2005) Trace elements in agroecosystems and impacts on the environment. J Trace Elem Med Biol 19:125-140

Hua Q, Barbetti M, Rakowski AZ (2013) Atmospheric radiocarbon for the period 1950-2010. Radiocarbon 55:2059-2072

Hudson-Edwards KA, Macklin MG, Curtis CD, Vaughan DJ (1998) Chemical remobilisation of contaminated metals within floodplain sediments in an incising river system: implications for dating and chemostratigraphy. Earth Surf Process Landf 23:684-761

Key RM (1983) The geology of the country around Gaborone and Lobatse. Dist Mem, Geol Surv Botswana 5:230 
Köppen W (1936) Das geographische System der Klimate [The geographic system of climates]. In: Köppen W, Geiger R (eds) Handbuch der Klimatologie, vol 1. Part C, Berlin Borntraeger, pp 1-44

Legret MU, Pagotto C (1999) Evaluation of pollutant loadings in the runoff waters from a major rural highway. Sci Total Environ 235:143-150

Lowe K (1995) Geology and geochemistry of the Gaborone granite complex and Kanye volcanic formation, southeastern Botswana. MSc dissertation, University of the Witwatersrand

MacDonald DD, Ingersoll CG, Berger TA (2000) Development and evaluation of consensus-based sediment quality guidelines for freshwater ecosystems. Arch Environ Contam Toxicol 39:20-31

Mangani G, Berloni A, Bellucci F, Tatàno F, Maione M (2005) Evaluation of the pollutant content in road runoff first flush waters. Water Air Soil Pollut 160:213-228

Mapeo RBM, Wingate MTD (2006) SHRIMP U-Pb zircon age for the Segwagwa-Masoke igneous complex of southeastern Botswana and implications for the deformation history of the Achaean to Proterozoic Transvaal Supergroup of southern Africa. J Afr Earth Sci 54:97-106

McGill BM, Altchenko Y, Hamilton SK, Kenabatho PK, Sylvester SR, Villholth KG (2019) Complex interactions between climate change, sanitation, and groundwater quality: a case study from Ramotswa, Botswana. Hydrogeol J 27:997-1015

Megnounif A, Terfous A, Ghenaim A, Poulet JB (2007) Key processes influencing erosion and sediment transport in a semi-arid Mediterranean area: the Upper Tafna catchment, Algeria. Hydrol Sci J 52:1271-1284

Mengistu Tsidu G (2016) Southern Africa between $5^{\circ}$ and $30^{\circ} \mathrm{S}$ In: State of the Climate in 2015. Bull Am Meteorol Soc 97:192-S194

Millard A (2014) Conventions for reporting radiocarbon determinations. Radiocarbon 56:555-559

Modie BN (1999) The geology of the area around Mochudi. Geological Survey Botswana, Lobatse, Bull 48:122

Müller G (1969) Index of geoaccumulation in the sediments of the Rhine river. Geojournal 2:108-118

Müller G (1981) Die schwermetallbelstung der sedimente des neckars und seiner nebenflusse: eine estandsaufnahme. Chem. Zeitung $105,157-164$.

Munoz SE, Giosan L, Therrell MD, Remo JWF, Shen Z, Sullivan RM, Wiman C, O'Donnell M, Donnelly JP (2018) Climatic control of Mississippi River flood hazard amplified by river engineering. Nature 556:95-98

Parida BP, Moalafhi DB (2008) Regional rainfall frequency analysis for Botswana using L-moments and radial basis function network. Phys Chem Earth 33:614-620

Peraza-Castro M, Sauvage S, Sánchez-Pérez JM, Ruiz-Romera E (2016) Effect of flood events on transport of suspended sediments, organic matter and particulate metals in a forest watershed in the Basque Country (northern Spain). Sci Total Environ 569:784-797

Prusty BG, Sahu KC, Godgul G (1994) Metal contamination due to mining and milling activities at the Zawar zinc mine, Rajasthan, India. 1. Contamination of stream sediments. Chem Geol 112:275-291

Reimer PJ, Bard E, Bayliss A, Beck JW, Blackwell PG, Ramsey CB, Buck CE, Cheng H, Edwards RL, Friedrich M, Grootes PM, Guilderson TP, Haflidason H, Hajdas I, Hatté C, Heaton TJ, Hoffmann DL, Hogg AG, Hughen KA, Kaiser KF, Kromer B, Manning SW, Niu M, Reimer RW, Richards DA, Scott EM, Southon JR, Staff RA, Turney CSM, van der Plicht J (2013) IntCal13 and MARINE13 radiocarbon age calibration curves 050000 years calBP. Radiocarbon 55:1869-1887

Romero-Díaz A, Alonso-Sarriá F, Martínez-Lloris M (2007) Erosion rates obtained from check-dam sedimentation (SE Spain). A multimethod comparison. Catena 71:172-178
Saft M, Western AW, Zhang L, Peel MC, Potter NJ (2015) The influence of multiyear drought on the annual rainfall-runoff relationship: an Australian perspective. Water Resour Res 51:2444-2463

Saft M, Peel MC, Western AW, Zhang L (2016) Predicting shifts in rainfall-runoff partitioning during multiyear drought: roles of dry period and catchment characteristics. Water Resour Res 52:9290 9305

Soler M, Regüés D, Latron J, Gallart F (2007) Frequency-magnitude relationships for precipitation, stream flow and sediment load events in a small Mediterranean basin (Vallcebre basin, eastern Pyrenees). Catena 71:164-171

Statistics Botswana (2018) Botswana environment statistics - Natural disasters digest 2017. Gaborone, November 2018

St-Jean G, Kieser WE, Crann CA, Murseli S (2017) Semi-automated equipment for $\mathrm{CO} 2$ purification and graphitization at the A.E. Lalonde AMS Laboratory (Canada). Radiocarbon 59:941-956

Tang Z, Zhang L, Huang Q, Yang Y, Ni Z, Cheng J, Yang J, Wang Y, Chai M (2015) Contamination and risk of heavy metals in soils and sediments from a typical plastic waste recycling area in North China. Ecotoxicol Environ Saf 122:343-351

Taylor MP, Hudson-Edwards KA (2008) The dispersal and storage of sediment-associated metals in an arid river system: the Leichhardt River, Mount Isa, Queensland, Australia. Environ Pollut 152:193-204

Taylor MP, Kesterton RGH (2002) Heavy metal contamination of an arid river environment: Gruben River, Namibia. Geomorphol 42:311-327

Toteng EN (2018) Popular community perceptions on flood disasters and climate change issues in Botswana. Botsw J Technol 23:61-85

Tsheko R (2003) Rainfall reliability, drought and flood vulnerability in Botswana, Gaborone. Water SA 29:389-392

Turnbull JC, Mikaloff Fletcher SE, Ansell I, Brailsford GB, Moss RC, Norris MV, Steinkamp K (2017) Sixty years of radiocarbon dioxide measurements at Wellington, New Zealand: 1954-2014. Atmos Chem Phys 17:14771-14784

Vaezi AR, Abbasi M, Keesstra S, Cerdà A (2017) Assessment of soil particle erodibility and sediment trapping using check dams in small semi-arid catchments. Catena 157:227-240

Varol M (2011) Assessment of heavy metal contamination in sediments of the Tigris River (Turkey) using pollution indices and multivariate statistical techniques. J Hazard Mater 195:355-364

Wen Z, Allen HE (1999) Mobilisation of heavy metals from Le An River sediment. Sci Total Environ 227:101-108

Yang, Y., T. R. McVicar, R. J. Donohue, Y. Zhang, M. L. Roderick, F. H.S. Chiew, L. Zhang, and J. Zhang (2017), Lags in hydrologic recovery following an extreme drought: Assessing the roles of climate and catchment characteristics, Water Resour. Res., 53, 48214837, https://doi.org/10.1002/2017WR020683.

Yao Q, Wang X, Jian H, Chen HA, Yu Z (2015) Characterization of the particle size fraction associated with heavy metals in suspended sediments of the Yellow River. Int J Environ Res Public Health 12:6725-6744

Zhao T, Yang M, Walling DE, Zhanga F, Zhang J (2017) Using check dam deposits to investigate recent changes in sediment yield in the Loess Plateau, China. Glob Planet Chang 152:88-98

Zhu L, Liu J, Xu S, Xie Z (2017) Deposition behavior, risk assessment and source identification of heavy metals in reservoir sediments of Northeast China. Ecotoxicol Environ Saf 142:454-463

Publisher's note Springer Nature remains neutral with regard to jurisdictional claims in published maps and institutional affiliations. 